NBER WORKING PAPER SERIES

\title{
TARGET LOANS, CURRENT ACCOUNT BALANCES AND CAPITAL FLOWS: THE ECB'S RESCUE FACILITY
}

\author{
Hans-Werner Sinn \\ Timo Wollmershaeuser \\ Working Paper 17626 \\ http://www.nber.org/papers/w17626 \\ NATIONAL BUREAU OF ECONOMIC RESEARCH \\ 1050 Massachusetts Avenue \\ Cambridge, MA 02138 \\ November 2011
}

We thank Jürgen Gaulke, Marga Jennewein, Michael Kleemann, Paul Kremmel, Wolfgang Meister, Beatrice Scheubel, Heidi Sherman and Christoph Zeiner for technical support, and in particular Julio Saavedra. We also thank Mario Draghi, Otmar Issing, Georg Milbradt, Helmut Schlesinger, Christian Thimann, Gertrude Tumpel-Gugerell, Jean-Claude Trichet and Martin Wolf for in-depth conversations, without implying in any manner whatsoever that they adhere to our arguments. The train of arguments and the most essential charts have already been presented by H.-W. Sinn at the following events: internal seminar, Banca d'Italia, 22 April 2011; public lecture, Humboldt University Berlin, 9 May 2011; Introduction, Munich Economic Summit, 19 Mai 2011. We thank Michael Burda for serving as the formal discussant for the Berlin lecture. This is an updated version of the one presented and discussed at a press briefing on 22 June 2011 in Frankfurt. We thank the participants for their valuable comments. The views expressed herein are those of the authors and do not necessarily reflect the views of the National Bureau of Economic Research. An online video of the Berlin presentation is available at: http://www.cesifo-group.de/berlinvideo

NBER working papers are circulated for discussion and comment purposes. They have not been peerreviewed or been subject to the review by the NBER Board of Directors that accompanies official NBER publications.

(C) 2011 by Hans-Werner Sinn and Timo Wollmershaeuser. All rights reserved. Short sections of text, not to exceed two paragraphs, may be quoted without explicit permission provided that full credit, including $(\subset$ notice, is given to the source. 
Target Loans, Current Account Balances and Capital Flows: The ECB's Rescue Facility Hans-Werner Sinn and Timo Wollmershaeuser

NBER Working Paper No. 17626

November 2011

JEL No. E50,E58,E63,F32,F34

\begin{abstract}
The European Monetary Union is stuck in a severe balance-of-payments imbalance of a nature similar to the one that destroyed the Bretton Woods System. Greece, Ireland, Portugal, Spain and Italy have suffered from balance-of-payments deficits whose accumulated value, as measured by the Target balances in the national central banks' balance sheets, was 404 billion euros in August 2011. The national central banks of these countries covered the deficits by creating and lending out additional central bank money that flowed to the euro core countries, Germany in particular, and crowded out the central bank money resulting from local refinancing operations. Thus the ECB forced a public capital export from the core countries that partly compensated for the now reluctant private capital flows to, and the capital flight from, the periphery countries.
\end{abstract}

\author{
Hans-Werner Sinn \\ Ifo Institute - \\ Leibniz Institute for Economic Research \\ at University of Munich \\ Poschingerstr. 5 \\ 81679 Munich \\ GERMANY \\ and NBER \\ sinn@ifo.de \\ Timo Wollmershaeuser \\ Ifo Institute -- Leibniz Institute \\ for Economic Research \\ at University of Munich \\ Poschingerstrasse 5 \\ 81679 Munich \\ Germany \\ wollmershaeuser@ifo.de
}




\section{Introduction ${ }^{1}$}

This paper investigates the Target balances, an accounting system hidden in remote corners of the balance sheets of the Eurozone's National Central Banks (NCBs), to analyze the Eurozone's internal imbalance. It shows that the Target surpluses and deficits basically have to be understood as classical balance-of-payments surpluses and deficits as known from fixedexchange-rate systems. To finance the balance-of-payments deficits, the European Central Bank (ECB) tolerated and actively supported voluminous money creation and lending by the NCBs of the periphery at the expense of money creation and lending in the core. This has shifted the Eurozone's stock of net refinancing credit from the core to the periphery and has converted the NCBs of the core into institutions that mainly borrow and destroy euro currency rather than print and lend it. The reallocation of refinancing credit was a public capital flow through the ECB system that helped the crisis countries in the same sense as the official capital flows through the formal euro rescue facilities (EFSF, EFSM and the like) did, but it actually came much earlier, bypassing the European parliaments. It was a rescue program that predated the rescue programs.

As we will show, in the three years 2008-2010, Target credits financed almost the entire current account deficits of Portugal and Greece and a quarter of the Spanish one. In the case of Ireland, they financed a huge capital flight in addition to the country's current account deficit. And, beginning with the summer of 2011, they have financed an even more vigorous capital flight from Italy. With the Italian capital flight, the Target credits have reached a new dimension and the ECB has entered a new regime, whose implications for the survival of the Eurozone should be discussed by economists. We can only touch upon the upcoming issues in this introductory piece.

\section{Target Loans through the Eurosystem}

The Target claims and liabilities that had accumulated in the NCBs' balance sheets until summer 2011 are shown in Figure 1. Germany, by that time, had claims on the Eurosystem amounting to 390 billion euros, and the GIIPS (Greece, Ireland, Italy, Portugal and Spain) in turn had accumulated a liability of 404 billion euros. The Target liabilities of Ireland and Greece alone were 119 and 96 billion euros, respectively.

\footnotetext{
1 This is an updated and abbreviated version of an earlier discussion paper of June 2011 (Sinn and Wollmershäuser, 2011) presented as a plenary lecture to the August 2011 IIPF congress in Ann Arbor, Michigan. It takes the Italian capital flight beginning in August 2011 into account. The train of arguments and the most essential charts of this paper have already been presented by H.-W. Sinn at the following events: internal seminar, Banca d'Italia, 22 April 2011; public lecture, Humboldt University Berlin, 9 May 2011; Introduction, Munich Economic Summit, 19 Mai 2011. An online video of the Berlin presentation is available at: http://www.cesifo-group.de/portal/page/portal/ifoHome/c-event/c3individualevents/_event_20110509. By now the topic has been also discussed in a scholarly way by a number of German authors in a special issue of Ifo Schnelldienst. See ifo Institut (2011) with contributions of H. Schlesinger; W. Kohler; C. B. Blankart; M. J. M. Neumann; P. Bernholz; T. Mayer, J. Möbert and C. Weistroffer; G. Milbradt; S. Homburg; F. L. Sell and B. Sauer; I. Sauer; J. Ulbrich and A. Lipponer; C. Fahrholz and A. Freytag; U. Bindseil, P. Cour-Thimann and P. König; F.-C. Zeitler; K. Reeh; and H.-W. Sinn). Furthermore, the ECB published information on the economics of the Target balances for the first time in October 2011 (European Central Bank, 2011b).
} 
Figure 1: Target balances in the Eurozone (end of August 2011)

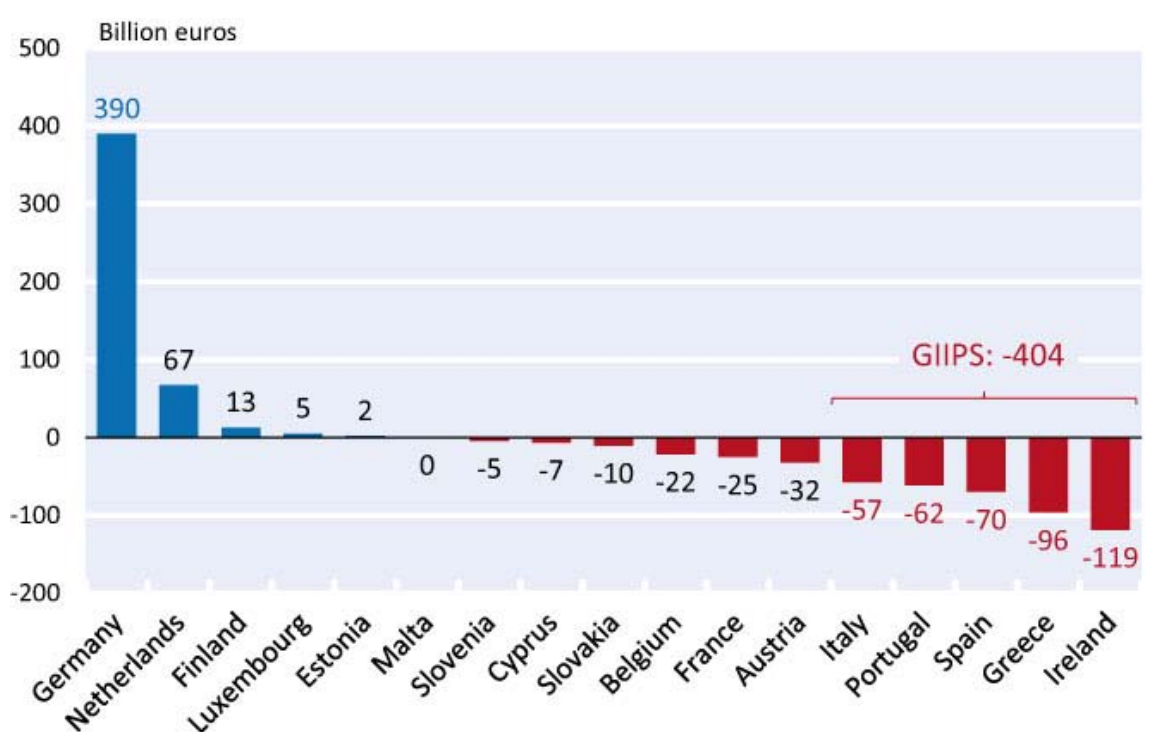

Note: The data are directly drawn from the balance sheets of the NCBs or calculated as proxy from the International Financial Statistics of the IMF, as explained in detail in the Appendix. Our method for calculating IMF proxies is identical to that adopted by the ECB. While Target balances in general should add up to zero, the residual of the data presented here is explained by the ECB's own Target liabilities stemming from asset transfers from NCBs, by Target claims of some non-Eurozone NCBs that are connected to the Target payment system and which have converted euros into national currency, and by measurement errors resulting from differences between the true balance sheet data and the imperfect IMF proxies. See the Appendix for further details.

Source: Own calculations

The Target claims and liabilities are interest-bearing. ${ }^{2}$ Their interest rate equals the ECB's main refinancing rate. However, interest revenues and expenses are socialized within the Eurosystem. Since the NCBs belong to their respective sovereigns, the Target liabilities constitute gross government debt, even though they are not officially counted as such. For Greece this debt is $44 \%$ of GDP, for Ireland $76 \%$, for Italy $3 \%$, for Portugal $35 \%$, and for Spain 6\%.

The Target imbalances went unnoticed for a long time, because they are not shown on the ECB's balance sheet, given that they net out to zero within the Eurosystem. ${ }^{3}$ They can be found, however, if somewhat laboriously, in the NCBs' balance sheets under the "IntraEurosystem Claims and Liabilities" position. Furthermore, they can be found in the balanceof-payments statistics, where they are shown as a flow in the financial account under the "Other Financial Transactions with Non-residents" position of the respective NCBs and as a stock in the external position of the respective NCBs as "Assets/Liabilities within the Eurosystem". Interestingly enough, the ECB revealed in October 2011, in its first publication

\footnotetext{
${ }^{2}$ Deutsche Bundesbank (2011b, p. 170).

${ }^{3}$ Precisely speaking, they net out in the euro countries, the ECB and those EU member countries that also use the Target payment system. The latter cannot have a negative Target balance as they are not allowed to print euros.
} 
on the issue, that it does not possess a reporting system of its own, but constructs the data from the IMF statistics (thus following the method we had introduced in the June 2011 version of this paper; see also the Appendix to this paper). ${ }^{4}$

Many think that the Target imbalances are a normal side-effect of the Eurozone payment system, as they are wont to occur in a currency system. This assessment is contradicted, however, by the dramatic evolution shown in Figure 2, which, as we will show below, in all likelihood would not have been possible in the US system. The Target imbalances evidently started to grow by mid-2007, when the interbank market in Europe first seized up. Before that they were close to zero. German claims, for instance, amounted to barely 5 billion euros at the end of 2006 .

It is striking that a strong, albeit not perfect, correlation exists between the rise of the German Target claims and the rise in the Target liabilities of the GIPS (without Italy). Other countries were involved, but with relatively negligible amounts, as shown in Figure 1. The creditor countries included Luxembourg and the Netherlands, while the debtors included Austria, France, Belgium and Slovakia, and, in particular, Italy. But the key players are, evidently, the GIPS, Italy and Germany.

During the first three years of the crisis Italy was not involved. Figure 2 shows Italy among the countries having a Target claim until June 2011. However, from July 2011 on, when markets turned jittery about Italy, forcing the Berlusconi government to enact austerity measures, the country also became a Target debtor. The Target balance of the Bank of Italy fell by 110 billion euros in only three months, from +6 billion euros in June to -104 billion euros in September, of which -87 billion euros were accumulated in August and September alone. Thus, Italy is the main reason behind the Bundesbank's Target claims rising by 113 billion euros over the same three months, to 450 billion euros in September 2011.

By September 2011, the volume of Target credit drawn by the GIIPs countries from the Bundesbank through the ECB system far exceeded the official loans given to them by the Eurozone countries combined. Until July 2011 Greece had received 65 billion euros from the euro countries and the IMF; Ireland and Portugal had received 25.9 billion euros and 30.3 billion euros respectively within the framework of the European Financial Stabilisation Mechanism and the European Financial Stability Facility (EFSF). In total, the official Eurozone aid amounted to 172 billion euros. In comparison, the Target loans provided by the Bundesbank totaled 450 billion euros, as mentioned.

\footnotetext{
${ }^{4}$ European Central Bank (2011b, footnote 5). Cf. Sinn and Wollmershäuser (2011).
} 
Figure 2: Net claims of the NCBs resulting from transactions within the Eurosystem (TARGET)

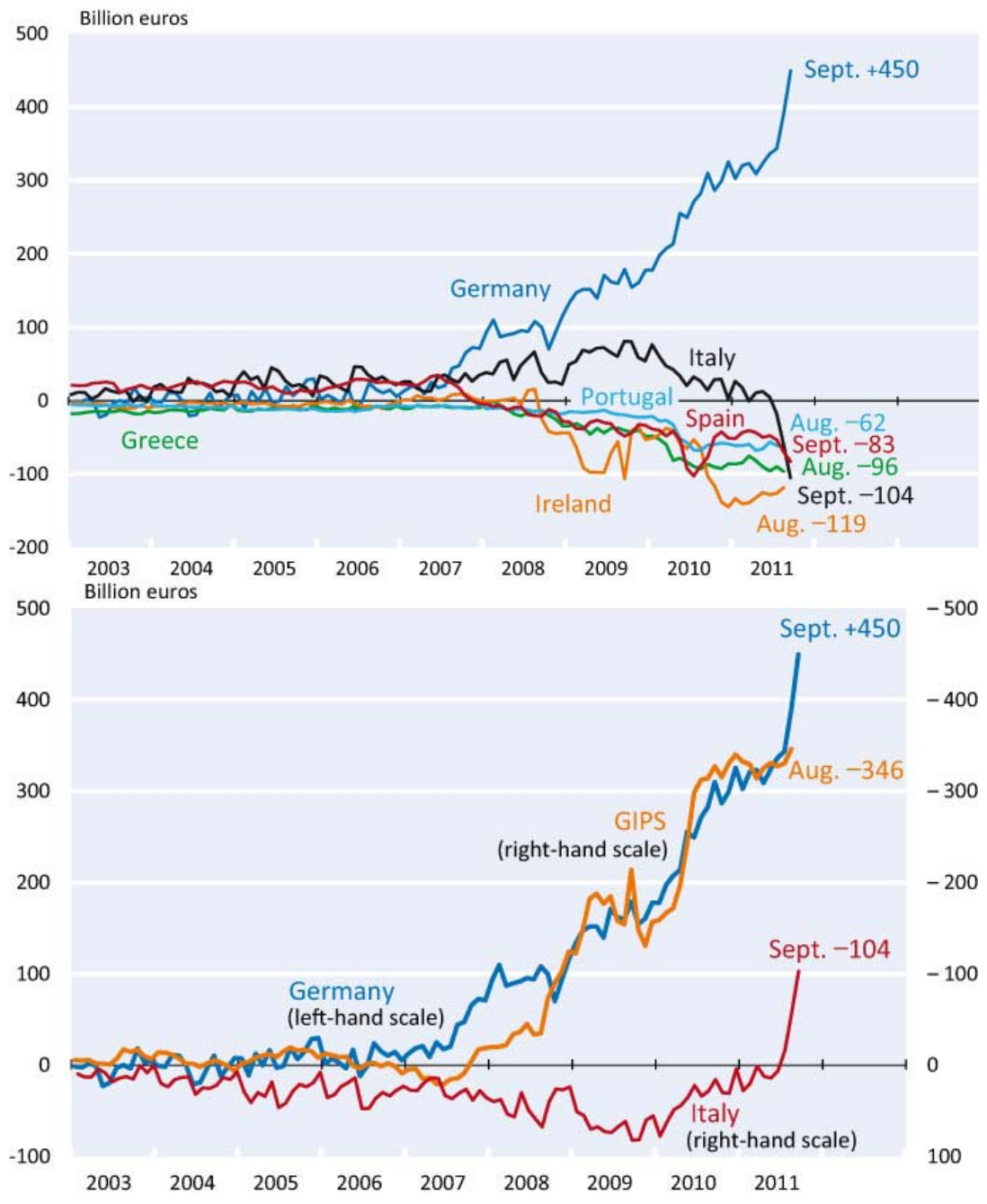

Sources: Own calculations; see Appendix.

\section{The Official Bundesbank and ECB Statements}

The Target debate began in Germany. After H.-W. Sinn brought the Target imbalances to public attention with articles in the German papers Wirtschaftswoche, Süddeutsche Zeitung and Frankfurter Allgemeine Zeitung, pointing out the risks they involved, ${ }^{5}$ the Bundesbank

\footnotetext{
5 See Sinn (2011a, 2011b). A number of columns were published subsequently. See Handschuch (2011), Krumrey (2011), Fischer (2011) and Whittaker (2011). In Sinn (2011e, 2011g) the Target issue was first interpreted in a balance-of-payment context. See also Sinn (2011f, 2011d). Two earlier articles by a Deutsche Bank official dealing with the Target issue were made available to us by Thomas Mayer, Chief Economist at the Deutsche Bank, on 9 May 2011: Garber (1989) analysed the protecting function of the Target system against possible speculative attacks during the transition from the virtual to the physical introduction of the euro in 2002 . Furthermore, there is another text by the Deutsche Bank, to the best of our knowledge an internal paper that had not been published, Garber (2010), in which some of the problems associated with the Target system were addressed, but devoid of any interpretation in terms of balance-of-payments or current account imbalances. An early warning of internal imbalances in the Eurozone payment system was expressed by Reeh (1999, 2001). In
} 
reacted with various, nearly identical statements. One day after the first publication by H.-W. Sinn on 21 February 2011, while confirming the figure calculated by the Ifo Institute of 326 billion euros in net claims of the Bundesbank to the end of $2010,{ }^{6}$ it tried to play down the importance of the issue in a press release. Other statements by the Bundesbank and, in October 2011, by the ECB followed. In essence, the banks said: ${ }^{7}$

1. The Target balances are a statistical item of no consequence, since they net each other out within the Eurozone (Bundesbank).

2. Germany's risk does not reside in the Bundesbank's claims, but in the liabilities of the deficit countries. Germany is liable only in proportion to its share in the ECB, and if it had been other countries instead of Germany that had accumulated Target claims, Germany would be liable for exactly the same amount (Bundesbank and ECB).

3. The balances do not represent any risks in addition to those arising from the refinancing operations (Bundesbank and ECB).

4. A positive Target balance does not imply constraints in the supply of credit to the respective economy, but is a sign of the availability of ample bank liquidity (ECB).

All points are basically correct (and do not contradict what we said in previous writings), but they hide the problems rather than clarify them and deny the fundamental distortions in the euro countries' balances of payments which, as we will argue, are precisely measured by the Target balances. Reacting to the first version of this discussion paper, former Bundesbank President Schlesinger criticized the Bundesbank for playing down the Target problem. He argued that the Target claim is the most important item in the Bundesbank's balance sheet and an important part of Germany's foreign wealth, by no means only a "statistical item", as the Bundesbank argued. ${ }^{8}$

Point 1 is true, but irrelevant. Between a debtor and its creditor the balances net out to zero, but that does not make the creditor feel at ease if he doubts the debtor's ability to repay.

Point 2 is true if a country defaults, destroying the banks' collateral and causing a default of its NCB, while the Eurosystem as such survives. In this case the loss of the ECB's claims against the country is shared by all non-defaulting NCBs according to their capital shares. Should the disaster hit all GIIPS countries, Germany, for example, would be liable in proportion to its capital share in the ECB, namely about $43 \%$ of the 404 billion euros in GIIPS liabilities, i.e. around 170 billion euros. This was basically the calculation one of us published on 2 April (though assuming a 33\% loss, as the possibility of an Italian default was not yet considered). ${ }^{9}$ No speculation regarding the likelihood of such a scenario was made. The issue is the value-at-risk. However, if Italy and Spain default, this could mean the end of the Eurosystem, something that has been considered by Anglo-Saxon economists as possible if

Sinn (2011c) a figure was named for the risk for Germany represented by the Target imbalances and by other rescue systems of the euro countries and the IMF. An editorial comment on it was written by Beise (2011). Much attention attracted an Article in VOX (Sinn, 2011h) as well as an article by Martin Wolf in the Financial Times commenting on a lecture given by H.-W. Sinn on 19 May 2011 at the Munich Economic Summit (Wolf, 2011). An extended version of the VOX article in German was published as Sinn (2011i). In Sinn (2011j, 2011k) an attempt was made to clear some misperceptions and wrong interpretations on the issue that had been widely publicised on the Internet. Finally, the June 2011 CESifo Working Paper preceding this publication (Sinn and Wollmershäuser, 2011) contains a detailed reply to some critics of Sinn's early writings, pointing out that the differences of opinion arose mainly from misunderstandings.

${ }^{6}$ Sinn (2011a); Deutsche Bundesbank (2011a). (On its website, the Bundesbank press office had misdated this press release until the first version of this working paper came out, to 21 January 2011 , i.e. one month before Sinn's article was published in Wirtschaftswoche).

${ }^{7}$ Deutsche Bundesbank (2011a, 2011c). Deutsche Bundesbank, letter to the Ifo Institute of 18 March 2011. European Central Bank (2011b, p. 37). Similarly, Ruhkamp (2011).

${ }^{8}$ Schlesinger (2011).

${ }^{9}$ See Sinn (2011d). If the GIPS (not including Italy) default, Germany's share in the losses is $33 \%$. 
not probable. ${ }^{10}$ In this case, it cannot be taken for granted that the former members of the euro community would choose to honor their Target debts. Legally, this is a grey area, and here the Bundesbank and the ECB may not be fully correct. It cannot be ruled out that Germany in this scenario would have to write off its currently more than 450-billion-euro claims. This may be the largest threat keeping Germany within the Eurozone and prompting it to accept generous rescue operations such as those agreed on in October 2011.

While again true, the statement made in point 3 hides the unusual size of the liability risk implied by the Target credit. To be sure, this credit materializes through the Eurosystem's normal refinancing operations (as well as emergency loans, so-called Emergency Liquidity Assistance, ELA, guaranteed by the respective sovereign that some NCBs granted on their own against no or only insufficient collateral). But it does measure, as we will show below, the additional refinancing credit an NCB issues to finance the country's balance-of-payment deficit with other Eurozone countries. As such it does imply additional risk. It would not imply such additional risk if it were redeemed within a fiscal year through a transfer of interest-bearing assets as is the case in the US monetary system. This will be clarified in section 10.

Point 4, finally, is true, insofar as a positive Target balance signals generous liquidity provision in a country. But, as we will show in section 7 , it is precisely this abundance of liquidity that implies a crowding out of refinancing credit in Germany. The Target imbalances do measure an international capital export through the Eurosystem, and hence a public credit, mainly from Germany, to the GIIPS countries. This is not a net outflow of credit, private inflows and public outflows taken together, but in itself it is an outflow in the same sense as a public rescue credit from one country to another is such an outflow.

\section{What are the Target Balances?}

The term Target balances has created much confusion even among academics, because it is a catchy term with several meanings that are not obviously connected with each other at first glance.

1. The term TARGET is an acronym that stands for Trans-European Automated RealTime Gross Settlement Express Transfer. This refers to the European transaction settlement system through which the commercial banks of one country make payments to the commercial banks of another country.

2. Target balances are claims and liabilities of the individual central banks of the Eurozone vis-à-vis the European central bank system that are booked as such in the balance sheets of the NCBs.

3. Target balances measure accumulated deficits and surpluses in each euro country's balance-of- payments with other euro countries. Target liabilities are the portion of the original central bank money created by a given NCB that exceeds the stock of central bank money available in that NCB's jurisdiction and that was employed for the net acquisition of goods and assets from other euro countries. Correspondingly, Target claims measure the surplus of the stock of central bank money circulating in one country above the central bank money created "inside" this country, and which arose from the net sale of goods and assets to other euro countries. We call this surplus "outside money". 11

From an economic point of view, the third definition is particularly relevant for an

\footnotetext{
${ }^{10}$ Krugman (2010), Feldstein (1997), Friedman (1997a, 1997b); Friedman (2001) says: "Der Euro wird in 5 bis 15 Jahren auseinanderbrechen." ("The euro will collapse in 5 to 15 years").

${ }^{11}$ To the best of our knowledge these definitions were used in this context for the first time in Sinn (2011f).
} 
assessment of the Target balances, because it shows that the change in Target balances measures intra-euro balance-of-payments deficits and surpluses. The designation "inside" is applied to the stock of central bank money created via asset purchases and refinancing operations, as opposed to the "outside" stock that has flowed in via the Target accounts. ${ }^{12}$ Central bank money is the term for the money that the commercial banks hold in their accounts at their respective NCB and cash held by banks and the rest of the economy. Since Keynes, the term M0 is generally used in this case. Alternatively, this is called "monetary base" or "base money".

We emphasize that all data we employ is from official statistics and that we regard the national stock of central bank money booked in the respective NCB balance sheet as the actual stock of central bank money circulating in a country. To our knowledge there are no data on physical international cash circulation outside the banking system. Nobody knows how many suitcases full of cash are crossing the borders surreptitiously. Since there are no restrictions on international bank transfers in Europe but there is an obligation to declare larger cash transports, we presume that this portion was rather inconsequential in the time window we have examined.

In order to understand how the various Target definitions are related, it is necessary to understand how the payment transactions between banks are carried out. When a bank customer effects a transfer from one commercial bank to another, it is fundamentally central bank money that flows between the commercial banks. If a Greek purchaser of a good transfers money from his checking account to the checking account of a vendor at another Greek commercial bank, base money is taken from the central-bank account of his bank and put on the central-bank account of the vendor's bank. The bank that pays out in turn charges the checking account of the customer, and the recipient bank credits the payment amount to the vendor's checking account.

If the bank of the vendor is located in another euro country, Germany for example, the procedure is similar, only that now the payment flows via the Target system of the ECB. When the Greek NCB debits the account that the commercial bank of a Greek customer holds with it, it takes money out of the Greek economy and removes it from its balance sheet, indeed destroying it, and cables the payment order to the Bundesbank. Conversely, the Bundesbank follows the order, creates new money and transfers it to the account of the vendor's commercial bank. ${ }^{13}$ In exchange, the Greek NCB acquires a liability to the ECB, and the Bundesbank acquires a claim on the ECB.

Normally, the payments between the countries net out as they flow in both directions, and no Target balances accumulate. This is the case when a country that imports goods in net terms pays with money it receives from abroad through selling assets. The net sale of assets to other countries is a net capital import. (It includes straightforward borrowing, because borrowing means "selling" debt certificates.) Similarly, a country with an export surplus will use the money it earns abroad to buy assets from other countries. Thus, normally, private capital flows finance the trade flows, and the balance of payments is in equilibrium. Target claims and liabilities build up if there is a net flow of euro money across the borders, because then trade and asset flows no longer net out to zero. They obviously imply that a stock of outside money has been accumulated in the recipient country.

\footnotetext{
12 Our definitions remind of the definitions used by Gurley and Shaw (1960). As will be discussed below, in principle, outside money can also stem from the conversion of non-euro currencies, but as that item is negligible, given that the ECB does not intervene in the exchange market, by "outside money" in this paper we mean only euros that were originally issued abroad.

${ }^{13}$ In this paper we also speak loosely of "printing" instead of "creating" money, even though in many cases the money printing occurs only virtually in computer accounts. After all, only a fraction of the central bank money consists of banknotes and coins.
} 
In addition to asset flows resulting from the need to finance the trade flows, there are of course many cross-border asset flows in both directions. In fact, such flows constitute by far the largest fraction of international payment transactions. However, this does not in any way modify the statement about how the Target balances arise because the asset flows largely net out. Whatever the size of the gross cross-border capital transactions, it remains true that Target balances arise to the extent trade and asset flows do not balance. A Target deficit by definition is a net outflow of money to pay for a net inflow of goods and/or assets.

The Target balances shown in the NCB balance sheets are stocks rather than flows. The balances of the previous year are carried forward, interest is applied and the new Target flows are added to the old stocks. Thus, the balances listed in the balance sheets measure the balance-of-payments deficits and the balance-of-payments surpluses that have accumulated since the introduction of the euro.

When the Target system was established, it was assumed that any imbalances would be insignificant. As insiders have reported, the belief prevailed at the time that the balances would virtually net out daily, and it was therefore not considered necessary to install a mechanism that would effectively avoid imbalances. The Target credits were to have the character of short-term checking account credits to smooth out the peaks in monetary transactions. And in fact, the credits were very small, as Figure 2 shows, up to the outbreak of the financial crisis in summer 2007. Dramatic developments occurred only thereafter.

Initially, only large payments were channeled through the Target system. In addition to that system, the commercial banks of the respective national countries had their own, private clearing systems through which most payments were executed in the first place and netted out before international transfers were made. Since payments from country A to country B were mostly offset by payments from country B to country A within these private clearing systems, the Target system of the ECB was in fact only needed to transfer the international excess payments that could not be cleared. This changed, however, with the establishment of the Target-2 system in 2007. Since then, smaller payments are also increasingly carried out directly via the Target accounts of the ECB. Recently, two-thirds of the Target transactions had a volume of less than 50,000 euros, and the median value of the payments was only 10,000 euros. ${ }^{14}$ This modification did have a considerable influence on the Target system's transaction volume, but the net balances now booked there were not affected by the transaction volumes. From the very beginning, any change in the Target balances correctly showed the net money transfers between the banks of the individual euro countries. As a result, a consistent interpretation of the time series, as shown for example in Figure 2, is possible, and the rise of the Target balances shown in the figure since 2007 is not a statistical artifact. For that reason we speak of Target balances rather than Target- 2 balances as is often the case.

\section{An Example}

An example of a payment transaction in which Target credits and debits arise is shown in Figure 3. A Greek transportation company buys a German truck. With the bank transfer the money flows to the Greek central bank, disappears from its balance sheet and ceases to circulate in Greece. Conversely, the Bundesbank must carry out the transfer and to do this it creates new central bank money, outside money, that flows to the manufacturer via its commercial bank. A Target liability is assigned to the Greek central bank on the amount of the transfer vis-à-vis the ECB, and conversely the Bundesbank receives a Target claim on the ECB in exchange for "printing" the outside money that now circulates in its jurisdiction.

\footnotetext{
${ }^{14}$ European Central Bank (2010, 2011a).
} 
As regards the booking of the payment transactions, it does not matter what the Greek company buys in Germany. Instead of a truck it could be a German asset, for example a plot of land, a company, bonds or securities. Also the mere opening of a German bank account into which a Greek national wishes to transfer his money because he distrusts his own banks leads basically to the same payment transaction. By the same token, it follows that if a Greek sells a debenture to a German to finance the truck, the payments would net out and no Target imbalances would arise. This was the typical case before the breakdown of the interbank market in the summer of 2007. At that time, net imports of goods by Greece were financed with credit taken abroad, and no Target balances arose.

Figure 3: The origin of the Target balances (example)

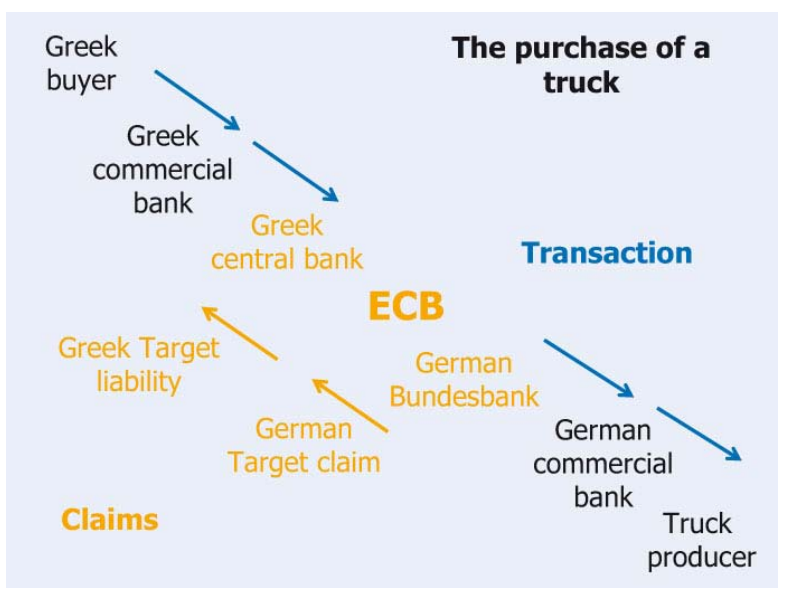

It lies in the nature of the transfer procedure that the Target balances are not merely balance-sheet clearing items but actual claims and liabilities with loan characteristics and which accrue interest. On the one side of the transaction, the Bundesbank had to create central bank money without receiving a marketable asset or a claim, as is usually the case, against a German commercial bank. Its Target claim against the ECB compensates for that. On the other side, the Greek central bank destroyed the central bank money without its assets or claims on the Greek banking system becoming any smaller. The Greek Target debt vis-à-vis the ECB is the counterpart to the missing claim reduction. Thus the Target liability of a country is a public credit provided to this country via the Eurosystem, and a Target claim of a country is a credit given to the Eurosystem - a public credit enabling the beneficiaries to buy foreign assets or goods.

An even clearer picture emerges if one looks directly at the balances of the NCBs as schematized in Figure 4 (with unrealistic numbers). ${ }^{15}$ Basically, in the balance sheet of an $\mathrm{NCB}$, the marketable assets (gold, government bonds etc.) as well as the loans granted to the commercial banks are booked on the left-hand side among the assets, while the central bank money it has created is booked on the right-hand side among the liabilities. Usually central bank money is further divided into cash and deposits of the commercial banks at the NCB, but this is not relevant here. In the schematic balances it is assumed that the marketable assets of the Greek central bank amount to 5 monetary units and that in addition it lent 15 units to the commercial banks. Since marketable assets were acquired in return for self-created euros, the monetary base equals 20. The same holds for the Bundesbank, only all numbers in the example are assumed to be ten times as large.

\footnotetext{
${ }^{15}$ For the structure of the central bank balance sheets, see Hawkins (2003). For a similar depiction of the posting operations, see Garber (1989).
} 
Figure 4: The Target balances in the balance sheets of the central banks (example)

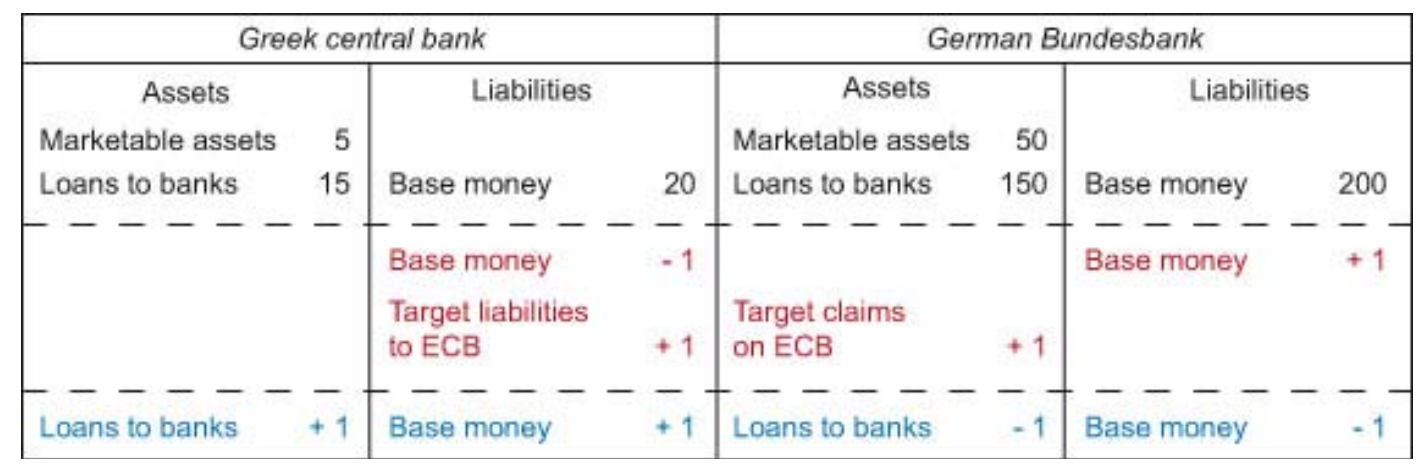

Let us now look at the possible payment transactions starting with the portion above the lower of the two dashed lines. We will examine the portion below this in the next section. If a unit of money is transferred from Greece to Germany, the monetary base in Greece decreases by this unit and it increases correspondingly in Germany. The changes in the balance-sheets are displayed below the first dashed line. Since the Greek balance sheet contracts and the German balance sheet lengthens, the Target balances are booked as clearing items, i.e. as a liability of the Greek central bank and as a claim of the Bundesbank, in both cases vis-à-vis the ECB.

The correctness of booking the Target balances as claims and liabilities follows however not only from some kind of booking mechanism, but from an economic perspective, primarily from the fact that economic goods or assets have moved from one country to another - in the above example a truck - without a movement of another good or asset in return. The claim that Germany receives through its Bundesbank on the ECB and that the latter has on the Greek NCB compensates for the transfer of the truck in the example, or in general, for the transfer of goods or assets.

The Target balances arise initially directly between the participating NCBs themselves. There is however an agreement, as the Bundesbank has reported, presumably between the individual NCBs, whereby at the end of the business day the balances are transformed into claims and liabilities vis-à-vis the Eurosystem as a whole. ${ }^{16}$ This procedure corresponds to the joint liability for losses on Target loans, as pointed out in section 3, and the socialization of interest earned from refinancing operations. As we will show below, with this procedure the Eurosystem has virtually created a kind of Eurobond.

\section{6. $\quad$ Reprinting Money}

The payment procedure described in the example that gives rise to Target balances apparently shifts the monetary base, taken by itself, from Greece to Germany. If that had been the only element behind the accumulation of Target balances shown in Figure 2, then the monetary base of the GIIPS countries should have disappeared long ago. In truth the monetary base of the GIIPS countries has not changed appreciably since the beginning of the crisis and during the accumulation of the Target balances; it even increased somewhat, from 291 billion euros to 332 billion euros. This is shown in Figure 5 below.

\footnotetext{
${ }^{16}$ Deutsche Bundesbank (2011c).
} 
Figure 5: Inside money, outside money and central bank credit of the GIIPS countries

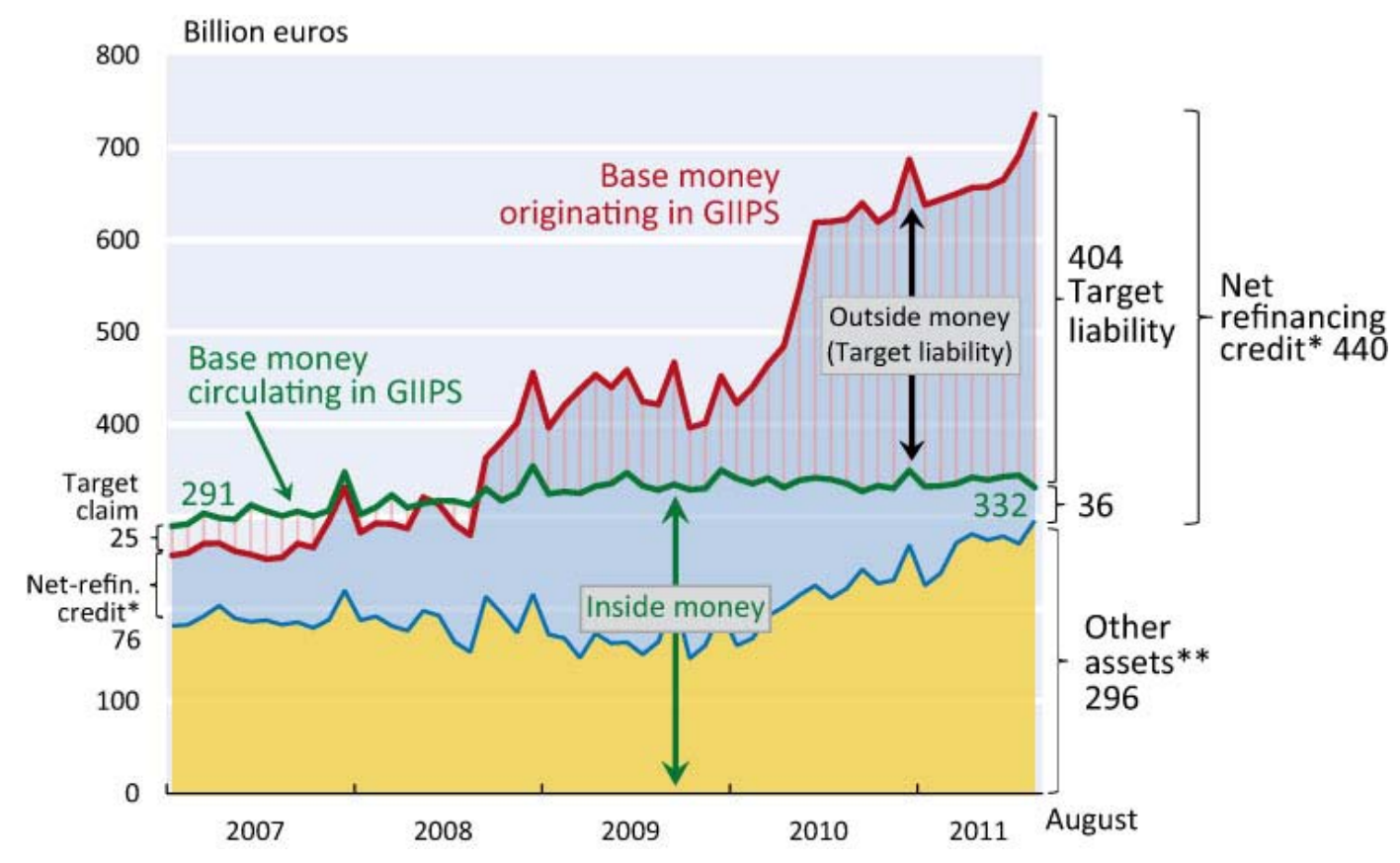

Notes: Inside money is the monetary base that circulates in a country or group of counties and originated there. Outside money is the Target balance, i. e. the base money that does not circulate in the country where it originated. Here, the stock of inside money is calculated as the sum of the banknotes put in circulation by the NCBs of the GIIPS and the cash deposits of the commercial banks with their respective NCB (basically minimum reserves). The banknotes put in circulation by the NCBs consist of the "statutory" banknote circulation calculated according to the NCB's capital share in the ECB and the intra-Eurosystem liabilities from the issuance of banknotes.

* "Net refinancing credit" is the stock of refinancing loans (including ELA credits) that the NCBs gave to commercial banks, net of the funds the NCBs borrowed from commercial banks, i.e. net of the deposit facility and the time deposits commercial banks hold with their $\mathrm{NCB}$, and net of other liquidity-absorbing operations. Refinancing loans comprise main refinancing operations, longer-term refinancing operations, the marginal lending facility and other liquidity-providing operations. ELA credits are emergency loans (Emergency Liquidity Assistance), primarily issued by the Central Bank of Ireland.

** "Other assets" comprise the net balance of the remaining assets and liabilities that are listed in the balance sheets of the NCBs. On the asset side this includes government bonds and securities that were not acquired within the framework of the normal refinancing operations. On the liability side, we have above all the capital and the reserves of the NCBs and liabilities in foreign currency.

Sources: Refinancing operations, deposits of the commercial banks, deposit facilities, banknote circulation, intraEurosystem claims related to the issuance of banknotes: Liquidity statistics or monthly balance-sheet statements of the NCBs; emergency loans of the Central Bank of Ireland (ELA): monthly balance sheet, other assets; gold and foreign currency: Eurostat, Official Foreign Reserves including gold; Target claims: see Appendix; calculations by the authors.

The base money flowing out of the GIIPS countries via international transactions was thus completely offset by the creation of new money by the GIIPS NCBs. In principle, new money that an NCB brings into circulation can arise from asset purchases and from credits of the central bank to the commercial banks (refinancing operations including ELA). It is evident in the chart, however, that the increase of the GIIPS countries' asset stocks only made a small contribution. The lion's share of the additional money creation apparently came about as the result of loans that the central banks granted the commercial banks within their jurisdictions. 
Stated the other way around, in the period under observation the NCBs of the GIIPS countries issued a huge amount of new central bank money by way of providing credit, which primarily flowed abroad as it was used for the purchase of foreign goods and assets. Only a small portion of this money remained at home as part of the monetary base.

In August 2011, the share of central bank money that was created through net refinancing operations and that remained as inside money at home was only 8 per cent (36 billion euros). Fully 92 per cent (404 billion euros) was circulating abroad as outside money. Moreover, $55 \%$ of the monetary base originating in the GIIPS (736 billion euros) had seeped to other countries and become outside money. This is reminiscent of the proportion of dollars circulating outside the US, which at the end of 2001 was estimated to be somewhat more than half of the monetary base. ${ }^{17}$ It is significantly more than the share of deutschmarks circulating outside Germany in the mid-1990s, which was a bit less than a third of the monetary base. ${ }^{18}$

The build-up of the Target balances has given rise to the unusual situation that now prevails in the Eurozone. The monetary base in the GIIPS countries, as is usual in closed currency areas, consists of one component that arose from asset purchases, and another that resulted from net refinancing operations of the central banks with the commercial banks. However, in other euro core countries, particularly Germany (see Figure 1), there is in addition outside money that flowed in via the Target accounts. The central banks of these countries had to create this central bank money in order to fulfill the transfer orders.

The reason for the excessive granting of refinancing credit and thus the creation of central bank money in the GIPS was obviously the financial crisis. Because of the interest-rate convergence that the euro brought about, and also because the Basel system allowed commercial banks to hold government bonds at zero-risk weighting, i.e. without any equity backing, capital flowed for years without hesitation to the southern and western periphery of the Eurozone, triggering an inflationary boom in these countries. ${ }^{19}$ But the flow of capital ran dry, and even partly reversed itself, when the American financial crisis prompted investors there and in Europe to revise their risk assessment. ${ }^{20}$ Market interest rates for the GIPS rose because investors demanded high risk premiums compared to safe German government bonds. In this situation, the possibility for the GIPS banks of getting credit at low interest rates from their respective NCB became much too inviting. The ECB itself encouraged borrowing by reducing its main refinancing rate from 4.25\% in October 2008 to just one per cent in May 2009, and adopting a full-allotment policy as early as October 2008. Full allotment means that the ECB was willing to grant the commercial banks credit in any amount they wished with maturities of up to one year, provided they were able to offer collateral. In addition, the ECB successively reduced its quality requirements on the collateral and successively extended the deadline it had announced for returning to normal collateral requirements (see Table 1).

\footnotetext{
${ }^{17}$ United States Treasury Department (2003).

18 Seitz (1995); see also Sinn and Feist (1997). To be sure, the difference is that the monetary creation gain (seignorage) in the form of interest yields on the newly created and loaned money is socialized in the Eurosystem, while in the case of currency circulating outside the jurisdiction of the note-issuing central bank a regular income in the form of interest yield on the externally circulating currency remains at that bank.

19 See Sinn (2010a, p. 143; 2010 d; 2011 1); Sinn, Buchen and Wollmershäuser (2011); European Economic Advisory Group (2011).

${ }^{20}$ See Klepsch and Wollmershäuser (2011).
} 
Table 1: ECB collateral requirements

\begin{tabular}{l|l} 
Date & Minimum credit rating threshold \\
\hline Until 14 October & A- \\
2008 & BBB- \\
15 October 2008 & $\begin{array}{l}\text { Suspended for Greece* } \\
\text { 10 May 2010 }\end{array}$ \\
31 March 2011 & $\begin{array}{l}\text { Suspended for Ireland* } \\
\text { 7 July 2011 }\end{array}$
\end{tabular}

* For debt instruments issued or guaranteed by the government. Sources: European Central Bank, Press Releases.

Taking this into consideration, the example of the Greek buyer of a truck must be modified. He obviously does not pay for his truck with money he possesses, but he borrows it from his bank, and the bank, because of the difficulties of raising funds in the interbank market, borrows it from its NCB. The Greek NCB thus creates the money that the haulage firm needs for the transfer to Germany. In Greece, money is now created, lent, destroyed when transferred via the Target system, and then created anew in Germany by the Bundesbank, which transfers it to the account of the commercial bank of the truck producer. Figure 6 shows the expanded payment process.

Figure 6: Credit creation and Target balances (example)

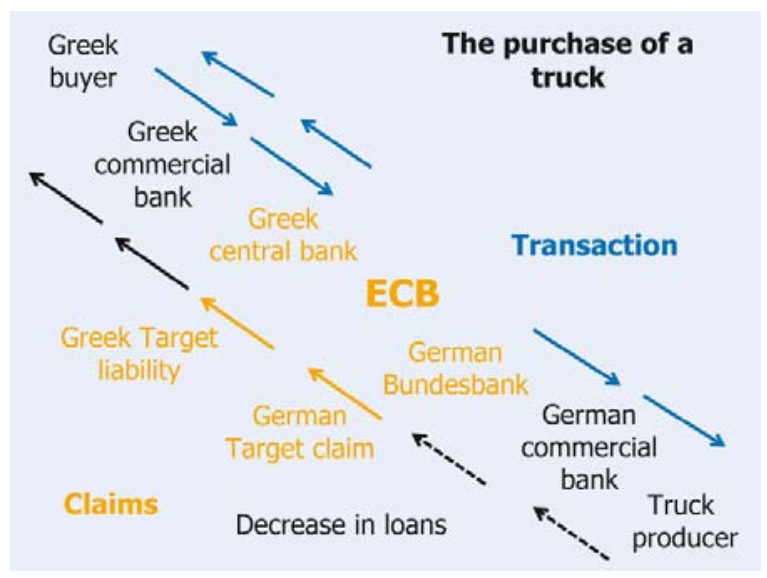

\section{How the Outside Money Crowds out the Refinancing Credit in the Core}

The creation of new credit in the deficit country does not end the payment processes, as the commercial banks of the exporting country, in our example Germany, and their private customers do not need the additional liquidity that they receive through the payment, given that the outflow of credit that had financed the Greek purchases has ceased to take place. Banks do not hold excess liquidity, because it involves interest costs, and their customers also 
try to keep their liquidity low, for the same reasons. Thus, German commercial banks will either borrow a correspondingly lower amount of central bank money from the Bundesbank when central bank money flows in through the international Target payment system, or they will place the unneeded liquidity on the ECB deposit facility or time deposit to collect interest. In either case the refinancing credit net of such interest-bearing deposits will fall by the amount of outside money coming in through foreign purchases of goods or assets. The stock of inside money, and hence net refinancing credit, is crowded out by the outside money originating from the GIIPS. ${ }^{21}$ This is indicated by the dashed arrows in the lower part of Figure 6. Overall, there is a relocation of refinancing credit from Germany to Greece, without a concurrent change in the monetary base either in Greece or Germany. In the balance-ofpayments statistics this phenomenon is officially called a capital export from Germany to other Eurozone countries.

In the exemplary system of accounts shown in Figure 3, the credit shift implies a lengthening of the Greek central bank's balance sheet and a reduction of the Bundesbank's balance sheet, as shown below the dashed line. In Greece, the central bank lends the commercial banks an additional unit of central bank money, while in Germany the Bundesbank lends one unit less. The monetary base in both countries remains unchanged, but the credit given by the Bundesbank declines by one unit, while it rises by one unit at the Greek central bank.

The shift of central bank credit from Germany to the GIIPS is a result of a limited demand for central bank money by the commercial banks, not a limited supply as some readers of our previous publications have assumed. At a given interest rate, money demand is determined by the economic activity and the payment habits prevailing in the country. That is why the inflowing liquidity crowds out the refinancing credit.

Figure 7 shows the common depiction of the base money demand curve. The lower the interest rate, the higher the demand for central bank money, as the interest rate measures the opportunity cost of not investing that money in other assets. The demand for central bank money may be understood best as the stock of central bank money that banks hold as liquidity and minimum reserves, and which private non-banks keep on average for normal payment processes.

Let us assume that the ECB follows a full-allotment policy, as it has done throughout the crisis. The banks, and indirectly the other economic agents supplied by them, may borrow as much central bank money as they wish to. But at the given refinancing rate they only want to realize point $\mathrm{A}$ and therefore demand only the amount of money that is shown by the arrow pointing to the abscissa. ${ }^{22}$

\footnotetext{
${ }^{21}$ For the crowding out argument based on the assumption of a limited liquidity demand see Sinn $(2011 \mathrm{e}, 2011 \mathrm{~h}$, $2011 \mathrm{k})$. Surprisingly, this argument has often been misrepresented in secondary writings, perhaps because the term "crowding out" was interpreted as implying supply constraints. To understand the term better, the reader may think of the example of a product market where a new competitor crowds out the incumbent firms because demand is limited, or Friedman's seminal crowding-out example where free public school meals for children crowd out private meals. See Friedman (1962, Chapter VI).

${ }^{22}$ The position of point A is not necessarily constant, as over the course of time the money demand curve might move to the right when there is real economic growth and inflation. It may also move to the right in times of crisis, when asset owners distrust other forms of investment. Still, given all the other determinants and given the interest rate, point $\mathrm{A}$ occupies a given position.
} 
Figure 7: Non-GIIPS base money demand, full allotment, and the crowding out of central bank credit

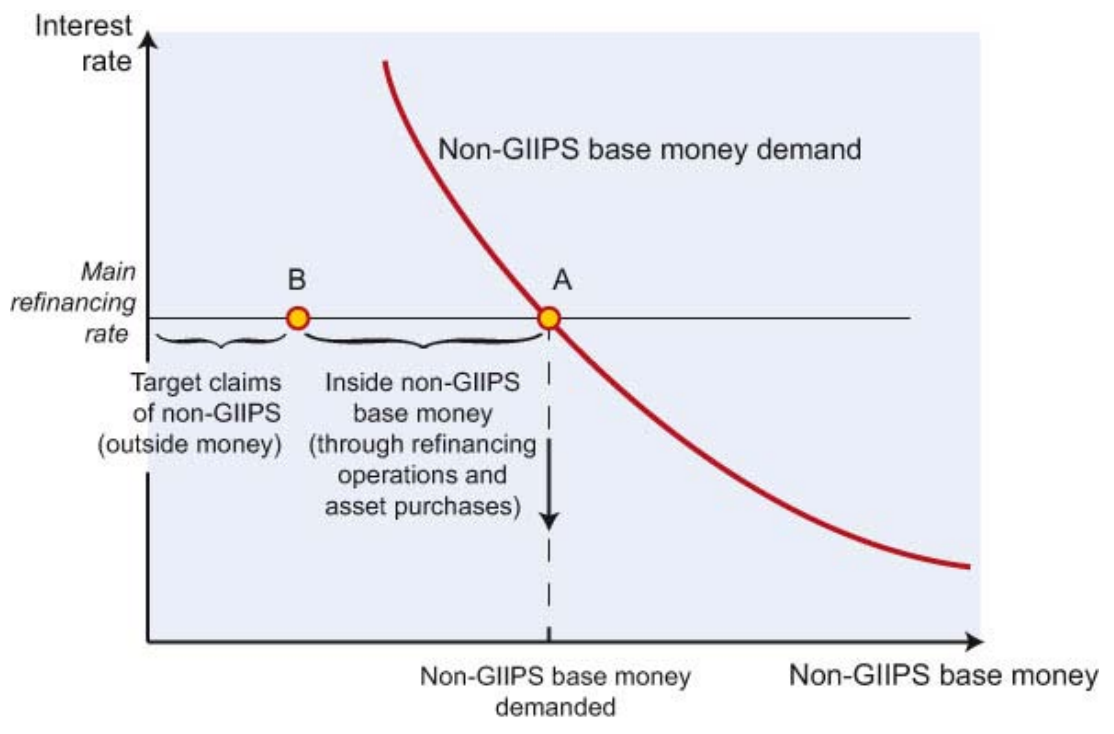

If as a result of the payments flowing in via the Target system the NCB is forced to deliver new central bank money to the banks without lending it to them, i.e. to create outside money, this automatically crowds out the inside money, i.e. the monetary base generated through refinancing operations or asset purchases. Given the time paths of marketable assets that the NCBs hold in their balance sheets, the inflow of central bank money from abroad has no influence on the monetary base in the recipient country and displaces the central bank refinancing credit one to one.

The crowding-out of one country's refinancing credit by the other's provision of such credit would happen a fortiori if the ECB were to control the aggregate monetary base through its own policy, as it did before the outbreak of the financial crisis by way of variable-rate tenders and as was standard at the Bundesbank when it still commanded the deutschmark. That is the more trivial theoretical case.

The crowding out of refinancing credit is well known from the times when the Bretton Woods System forced the European central banks to maintain a fixed exchange rate vis-à-vis the US dollar. At that time, the US had financed its current account deficit by printing and lending more dollars than the US needed for internal purposes. ${ }^{23}$ The dollars were flowing to, among other recipients, German exporters who had them exchanged by the Bundesbank for deutschmarks. The "dollar-deutschmarks" was outside money in the German system, crowding out the Bundesbank's inside money resulting from refinancing operations on a oneto-one basis. The statistics at the time reported a public capital export from Germany to the US via the central bank system. Many observers had suspected that the Bundesbank tolerated this public capital export in order to help finance the Vietnam war.

While the Bundesbank invested the dollars it received into US Treasury bills, the Banque de France insisted that the US government convert them to gold from Fort Knox. This destroyed the Bretton Woods system in the period 1968-1971. Today the Bundesbank converts the "GIIPS euros" into "German euros", which then crowd out the "refinancing-

\footnotetext{
${ }^{23}$ Cf. Kohler (2011) for a comparison with the Bretton Woods crisis and Tornell and Westermann (2011) for a comparison with the Mexican Tequila Crisis.
} 
credit euros" issued by the Bundesbank, and instead of foreign currency or foreign assets, the Bundesbank receives Target claims on the Eurosystem as shown in Figure 2.

The fact that the Bundesbank holds large Target claims against the ECB was presented to us in an exchange with an Irish colleague as the conscious investment preference of the Bundesbank. While other central banks held their assets in the form of gold or claims against the commercial banking system, it was supposedly the preference of the Bundesbank to build up claims against other central banks instead. This assessment of things misunderstands what was going on. The Bundesbank was unable to refuse the demands for carrying out payments to German recipients and the resulting creation of new money outside the refinancing operations with commercial banks. For this creation of money it automatically received claims on the Eurosystem. There was no conscious investment decision at all.

But of course, although imposed by the system, it was an investment nonetheless. The shifting of refinancing credit from Germany to the GIIPS was a capital export through the Eurosystem, a credit the Bundesbank gave to the GIIPS countries, enabling the latter to buy more goods or assets in Germany than otherwise would have been the case.

The possibility of drawing public credit through the Eurosystem amounted to a rescue facility before the rescue facility - i.e. a public credit helping the crisis-stricken countries that came before the official credit provision on which the parliaments of Europe decided in 2010 and 2011 (EFSF, EFSM and first Greece package). In terms of the right of disposition over economic resources, payment flows, international distribution of central bank money, and the liability involved, it was essentially identical to proportionately guaranteed short-term Eurobonds that must be bought by the core euro countries, with the resulting revenue being lent to the peripheral countries. Eurobonds such as these shift the disposition of economic resources from the core countries to the periphery in the same way that the Target credits do. Credit and money flow from the core countries to the periphery, and money comes back to buy goods or assets. Such bonds would also not change the distribution of the monetary base in Europe, and they would also allocate credit and thus the disposition of economic resources to the recipient countries at the expense of the creditor countries. Even the liability would be identical. If the credit-receiving country should go bankrupt, all euro countries would be liable in proportion to their capital shares in the ECB, which for each country is the average of the population size and share of GDP. Everything is basically the same as with Target credits. The only (irrelevant) difference is that with Eurobonds the credit involves a transfer of existing money, whereas the Target credits imply a relocation of the money-printing activity.

The provision of Target credit cannot be interpreted as a liquidity squeeze in Germany, as some readers have assumed. Of course it wasn't a liquidity squeeze, given that the crowding out of refinancing credit was caused by an inflow of liquidity into the core. And it was not even a credit squeeze. After all, the reason for the Target credits given by the Bundesbank was that private capital did not dare leave Germany and preferred to finance domestic endeavors, which were considered safer than foreign investments. Moreover, there was flight capital coming in from abroad that further enhanced the credit supply in Germany (recall that the example would lead to identical payments if the Greek firm bought German assets rather than a German truck). The abundance of capital supply was the main driver of the boom that Germany came to enjoy after the crisis. ${ }^{24}$ However, this does not detract from the fact that through public actions some, if not most, of the reluctant capital that had gathered in Germany ended up being channeled abroad. If country A gives country B a rescue credit this is a "signal", to use the language of the ECB, that country A has abundant credit, but it nevertheless is a credit outflow in and of itself, a publicly induced shift of command over real economic resources from country A to country B. This is simply a statement of fact, and not an interpretation or value judgment. This does not imply that there is a net outflow, private

\footnotetext{
${ }^{24}$ See Sinn $(2010 \mathrm{~b}$ and c $)$.
} 
and public flows taken together, but that there is a public credit flow that went contrary to market flows. If the private capital market was wrong, this policy was right, but if the private capital market was right, the policy was wrong. There are reasons to believe that the policy was right in the short term because markets were dysfunctional in the autumn of 2008, but there also is a case for fearing that it was and will be wrong in the long term as markets correctly assess that the GIIPS countries suffer from structural current account deficits stemming from wrong prices for goods, labor and assets that built up during the pre-crisis bubble. In the end, the main theorems of welfare economics suggest that markets are able to allocate capital efficiently among rivaling uses and do not need a central planning agency for correction, be it called ECB, EFSF or whatever.

\section{Why the Printing Presses of the Core were Replaced with Money Shredders}

Let us now dig further into the empirical details. The following two figures drawn from the NCB's balance sheets put real numbers to the general considerations of the previous section. Figure 8 shows that, as predicted, neither the evolution of the Eurozone's aggregate monetary base nor the evolution of its national components was disturbed by the cross-border money flows as measured by the growing Target imbalances. The German monetary base stayed on trend as did the aggregate monetary base. Thus, the inflow of outside money due to the granting of Target credit to the GIIPS must indeed have crowded out the refinancing credit in Germany. $^{25}$

Figure 8: Monetary base in the Eurozone

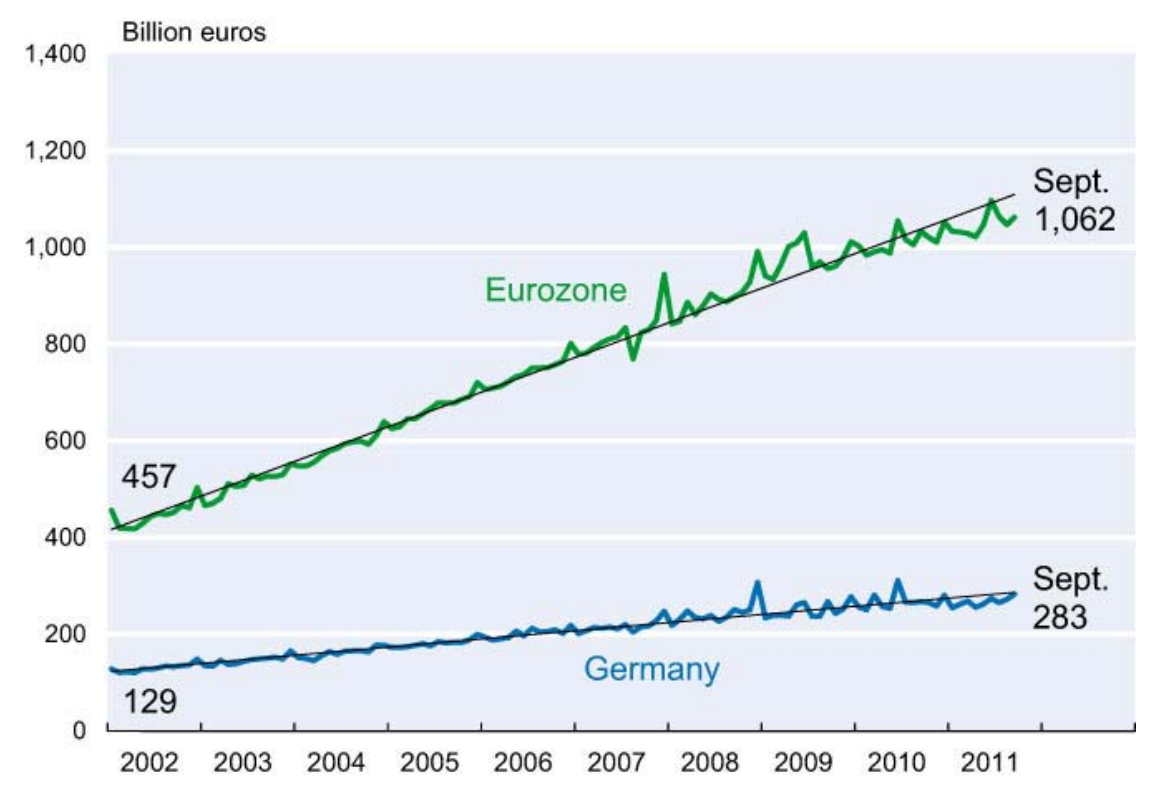

Note: The monetary base is defined net of (interest-bearing) deposit facilities.

Sources: See Figure 5; own calculations.

\footnotetext{
${ }^{25}$ It is obvious from Figure 8 that the stock of base money became a bit more volatile during the financial crisis, but this had no lasting effect on the trend. In 2009 many commercial banks feared a continuation of the crisis and converted short-term claims on other banks into deposit facilities. This temporarily increased the monetary base if defined according to a broad concept including such facilities (see Sinn and Wollmershäuser, 2011, Figure 8). However, the monetary base net of deposit facilities as defined here did not react significantly even at the peak of the crisis.
} 
Figure 9 strengthens this conclusion by illustrating the crowding-out process more explicitly. The figure is similar to Figure 5, but it shows percentages rather than absolute numbers and overlays it with another, inverted graph like the one shown there that represents the non-GIIPS countries. The entire euro monetary base is set equal to one hundred per cent. The thick line in the middle is the borderline between the monetary base of the GIIPS countries (measured from below) and the monetary base of the remaining euro countries (measured from above). The proportion of the monetary base held in the GIIPS countries $(32 \%)$ is roughly in line with their corresponding GDP share in the Eurozone (35\%).

The graph shows that the NCBs of the non-GIIPS countries, like those of the GIIPS countries, issued money by purchasing assets in the private sector and by providing refinancing credit. The share of the former has increased recently, due to the ECB's Securities Markets Program, forcing the NCBs to buy the government bonds of the GIIPS countries, about 120 billion euros until August 2011. While this in itself reduced the scope for providing refinancing credit, the outside money flowing in from the GIIPS in the form of Target credit obviously was much more important.

Figure 9: Origin of the monetary base in the Eurosystem (shares)

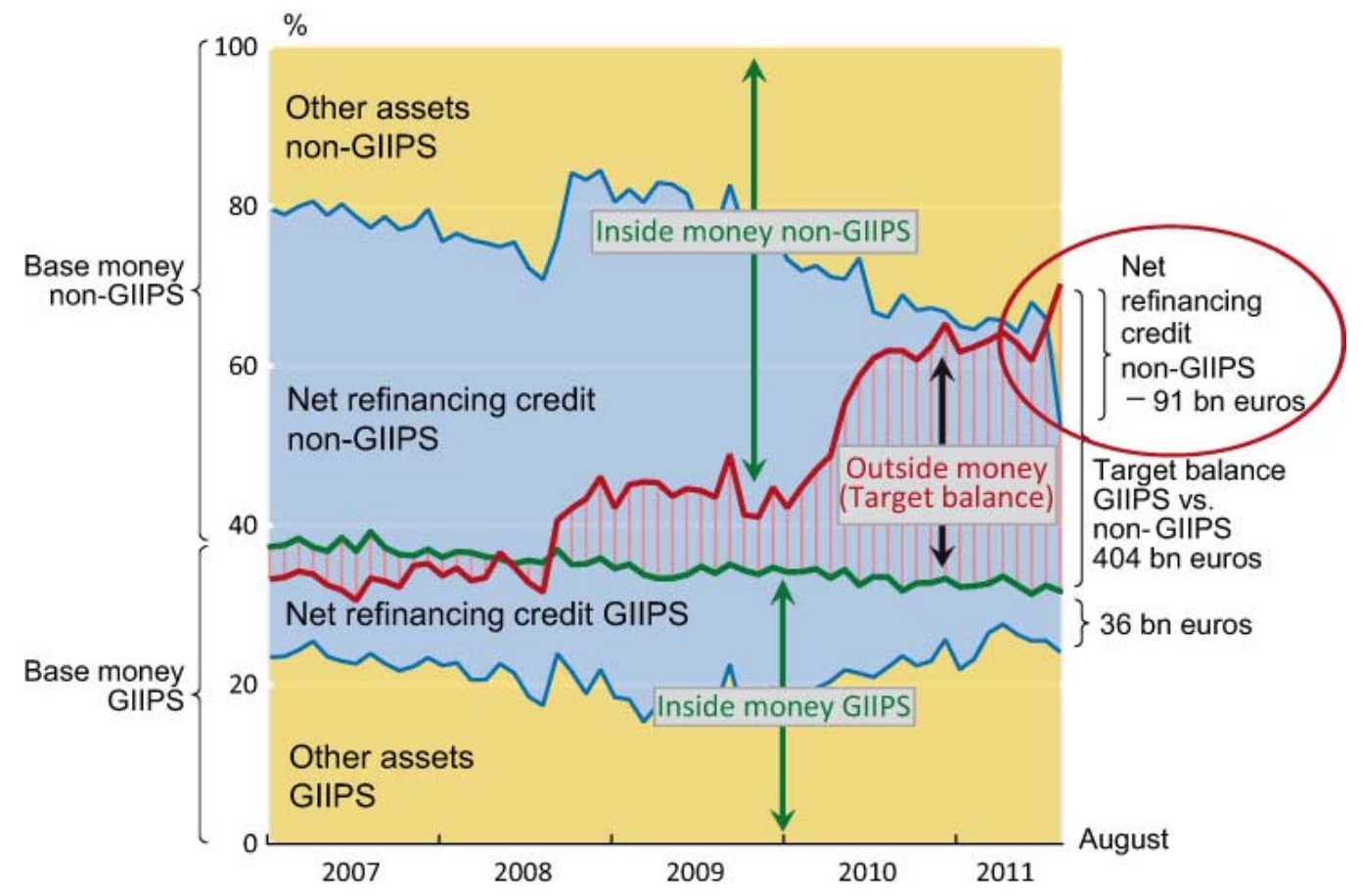

Note: The Target balance corresponds to the Target liabilities of the GIIPS NCBs to the Eurosystem as well as the Target claims of the remaining countries' NCBs (including the ECB) on the Eurosystem. It measures the central bank money that flowed from the GIIPS to the other countries of the Eurozone via international transactions. See also notes to Figure 5.

Sources: See Figure 5; own calculations.

While Figure 5 showed the dramatic expansion of Target credit in the GIIPS countries, Figure 9 shows that this expansion was large enough to wipe out the entire net refinancing credit in the non-GIIPS countries. It even made this credit negative in August 2011. While 
gross refinancing credit in the non-GIIPS countries amounted to 121 billion euros in August 2011, the deposit facilities and time deposits the commercial banks of these countries held with their respective NCBs was 212 billion euros, netting out to -91 billion euros. Thus, the NCB's of the non-GIIPS countries stopped lending to commercial banks and became netborrowers of central bank money. In the periphery countries, the printing presses were overheating, and the core countries had to replace their printing presses with paper shredders.

In the first version of this discussion paper, published in June 2011, we had predicted, by way of a mere trend extrapolation, that this would happen in 2013, but that did not take the dramatic acceleration of the crisis into account that came in the summer, when all of a sudden capital began to flee Italy (see Figure 2). Spain also cranked up its printing presses once again. As Figure 2 reveals, Italy reduced its positive Target balance during the year 2010 and became a Target borrower in the second half of 2011. As was mentioned above, in August and September 2011 alone, Italy's Target deficit increased by 87 billion euros. Ireland, however, remained by far the largest Eurozone Target borrower, as shown in Figure 1.

Figure 10 breaks down the time paths for net refinancing credit by country up to August 2011, showing how net refinancing credit of the GIIPS countries crowded out that of the other countries. In the figure, the Eurosystem's total net refinancing credit is set equal to one hundred per cent, and the middle areas show the shares of the individual countries in this total. It can be seen that the extra lending of the GIIPS drove an increasing wedge between the refinancing credit of the non-GIIPS and non-German countries (comprising France, Belgium, the Netherlands, Austria, Finland, Slovakia, Luxembourg, Slovenia, Cyprus, Estonia and Malta) on the one hand (the area on top) and Germany on the other (the area at the bottom), wiping out their refinancing credit entirely and turning both the group of countries and Germany into net borrowers of central bank money in the Eurozone as of August 2011. ${ }^{26}$

\footnotetext{
${ }^{26}$ On average for the years considered in the chart, Germany accounted for about $27 \%$ of the Eurozone's GDP. Thus, the credit share of Germany before the outbreak of the financial crisis was far above its economic weight. Because of the great proliferation of Pfandbriefe in Germany, which is a triply-secured kind of mortgage-backed instrument, the cost of procuring liquidity from the central bank was lower in Germany than in many other countries of the Eurozone (Chailloux, Gray and McCaughrin, 2008). German commercial banks therefore provided other commercial banks within the Eurozone with central bank money in considerable amounts (Deutsche Bundesbank, 2011c). As this concerned private capital exports, which corresponded to a current account surplus or other capital imports, there was no noticeable build-up of Target balances before the onset of the financial crisis. Other reasons could have been that Germany's payment transactions are very cash-intensive compared to other countries like France, that Germany has many foreign workers who make remittances in euros, and also that the Bundesbank has rather small stocks of gold and foreign exchange relative to the size of its monetary base, so that a larger part of the monetary base was created via lending.
} 
Figure 10: Shares in the Eurosystem's total net refinancing credit

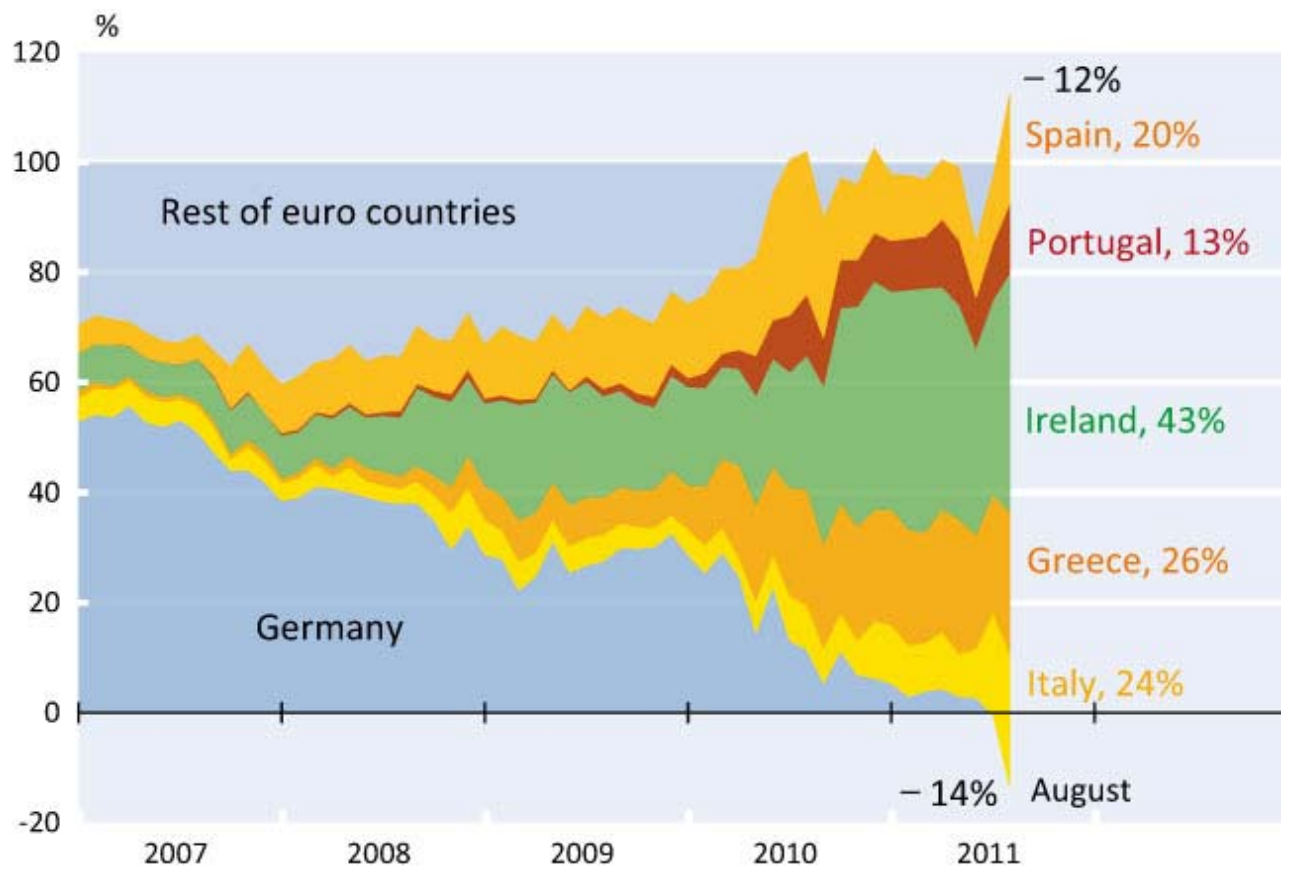

Note: See notes to Figure 5.

Sources: See Figure 5; own calculations.

As explained above, the reallocation of the Eurosystem's refinancing from the core to the periphery was made possible by the lowering of the quality of the collateral accepted by the ECB. When the demand for refinancing credit rose because private lenders became increasingly reluctant to export their capital to the GIIPS, the troubled commercial banks of these countries found it increasingly difficult to provide good securities. Thus, the ECB's policy actively helped to create the Target loans. Even that, however, was not enough in the Irish case. There, credit demand was so large that the troubled commercial banks in many cases were not able to provide any collateral at all. For this reason, the Central Bank of Ireland provided short-term emergency loans to these banks (Emergency Liquidity Assistance, or ELA) that recent estimates put at 56 billion euros by August 2011. Since their interest rate lies $2 \%$ to $3 \%$ above the current interest rate of the marginal lending facility, ${ }^{27}$ the taking on of these loans can only be explained with a clear lowering of the collateral requirements on the part of the Central Bank of Ireland. As ELA loans are largely outside the control of the Governing Council of the Eurosystem, their liability rests firstly only with the NCBs and their sovereign. The other NCBs in the Eurosystem are only liable for the Irish ELA loans if Ireland defaults. While the ELA loans are an important reason for the emergence of the Irish Target loans, they nevertheless accounted only for $14 \%$ of the Target credit given to the GIIPS countries by August 2011. The lion's share of the Target credit was issued via normal refinancing operations and represents a direct default risk for the other euro countries

\footnotetext{
${ }^{27}$ As the Irish Independent has written: "The interest rate paid by Irish banks on ELA is in the 'ball park' of 2pc$3 \mathrm{pc}$, informed sources said. The rate is based on the ECB's marginal lending facility of $1.75 \mathrm{pc}$, plus a 'penalty' reflecting the emergency nature of the aid." See http://www.independent.ie/business/irish/banks-pay-less-than3pc-interest-on-euro51bn-of-emergency-funding-2529378.html.
} 
if the collateral that the ECB required of its NCBs should prove insufficient, which all too often consists of government bonds or government-secured private bonds. ${ }^{28}$

\section{Target Credit, Current Account Imbalances and Capital Movements}

We now turn to the meaning of the Target loans in the context of the Euro countries' balance of payments. According to the third definition given in section 4, a country's Target debt measures the accumulated balance-of-payments deficit with other euro countries, i.e., the accumulated net outflow of central bank money for the net purchase of goods and assets from other euro countries (plus interest). Thus, the increase of a country's Target liability over one year, i.e. its Target deficit, equals the sum of (private and public) net capital exports and the current account deficit vis-à-vis other euro countries, as this is the size of the net outflow of central bank money to the other euro countries. A net capital export equals the net accrual of assets in other countries, and a current account deficit is basically defined as that part of the excess of imports of goods and services over exports that is not financed with transfers (gifts) from other countries. As was mentioned above, in the balance-of-payments statistics the net outflow of central bank money from a country (the Target deficit) is labeled quite correctly a capital import through the central bank system, i.e. it is a public credit between central banks. In the following, however, the terms "capital imports" or "capital exports" are meant to refer to credit flows between the private and public sectors not including the central bank, unless otherwise noted. Analogously, we do not include changes in the stocks of foreign currency in our standard definition of capital flows.

Let's call a euro country's Target deficit (i.e. the annual increase in its Target liability $T) \Delta T$, its current account deficit vis-à-vis all foreign countries $L$, its current account deficit vis-à-vis other non-euro countries $L_{n}$, its net capital exports to all foreign countries $K$ and its net capital exports to non-euro countries $K_{n}$. Then the country's Target deficit is ${ }^{29}$

$$
\begin{aligned}
\Delta T & =L-L_{n}+K-K_{n} \\
& =L+K-\left(L_{n}+K_{n}\right) .
\end{aligned}
$$

Here the term in parentheses in the second line of the equation measures the net acquisition of goods and assets from outside the Eurozone, which corresponds to a net outflow of foreign exchange. In a system of fixed exchange rates, this term could have a considerable size, because the Eurozone's NCBs would intervene in order to stabilize the exchange rates. For example, they could sell dollars for euros in order to permit euro citizens to acquire such goods and assets in net terms. But the Eurozone's NCBs don't do this, or if they do, they do so in only a minute volume. It was and is the declared policy of the ECB to let exchange rates float freely. Private changes in foreign cash holdings were probably equally negligible. Thus, a euro country's current account balances vis-à-vis non-euro countries can be assumed to be offset by identical balances in the capital accounts vis-à-vis such countries, and the term in parentheses approximates zero. ${ }^{30}$ The above equation then simplifies to

\footnotetext{
${ }^{28}$ See in particular Brendel and Pauly (2011), but also Fuest (2011) and Krugman (2011).

${ }^{29}$ This definition was first given in Sinn (2011e, 2011h) and Sinn and Wollmershäuser (2011). For a thoughtful explanation see also Homburg (2011). Cf. moreover Kohler (2011) and Mayer (2011).

${ }^{30}$ The term does include, however, the official accumulation of euro base money in the balance sheets of those non-Eurozone EU countries that participate in the Target2 transactions system (Bulgaria, Denmark, Latvia, Lithuania, Poland and, since July 2011, Romania). Cf. ECB (2011 b, p. 36, footnote 2) and the Appendix to this paper.
} 


$$
\Delta T \approx L+K=L-Z
$$

where $Z$ is the euro country's net capital imports from all foreign countries. The first term on the right-hand side says that an increase of the Target debt of a euro country equals the sum of the current account deficit vis-à-vis all foreign countries inside and outside the Eurozone and the net capital exports to them. Equivalently, the second term says that the increase of the Target debt equals that part of a euro country's current account deficit vis-à-vis all other countries that is not financed by (private and public) capital imports from the rest of the world.

Figure 2 showed that the Target balances of the GIPS (without Italy) countries were close to zero until 2007 , i.e. until shortly before the outbreak of the financial crisis, and only surged thereafter. Until 2007 the GIPS capital imports must therefore have been about as large as their current account deficits. All net purchases abroad were financed by a net inflow of capital. As public capital flows were minimal until then, the current account deficit was in fact financed with inflows of private capital. That is the normal case when a country has a current account deficit.

As explained, the situation changed after the temporary breakdown of the interbank market in August 2007. The GIPS Target liabilities then rose dramatically and reached a level of 340 billion euros by December 2010. By the same time Germany had accumulated Target claims worth 326 billion euros. (By August 2011 the two values had increased to 346 billion euros and 390 billion euros, respectively.) The increase in the Target liability of the GIPS countries in the three-year period $2008-2010$ amounted to 321 billion euros, while the increase in the Target claim of the Bundesbank amounted to 255 billion euros.

It is useful to confront this information with the current account balances of Germany and the GIPS. While the Target liability of the GIPS increased by 321 billion euros for the three years, their current account deficits together amounted to 363 billion euros. Thus, the GIPS received only 41 billion euros in normal capital imports, or just $11 \%$ of their joint accumulated current account deficit. $89 \%$ of the aggregate current account deficit (total capital import, broadly defined) was Target credit. Over the period Spain accumulated an additional Target debt of 46 billion euros, Portugal 54 billion euros, Greece 76 billion euros, and Ireland 145 billion euros.

By contrast, Germany's Target claims increased by 255 billion euros over the three years and its total current account surplus amounted to 430 billion euros. This implies that the Target credits granted by the Bundesbank covered $59 \%$ of the German current account surplus (total capital export) in the period $2008-2010$. Thus, Germany received marketable claims or assets against other countries for only $41 \%$ of its current account surplus.

It is even more striking to compare the additional Bundesbank Target claims (the 255 billion euros) with Germany's current account surplus with the rest of the Eurozone over the three years, which was 264 billion euros. ${ }^{31}$ The comparison shows that the rest of the Eurozone paid for its current account deficit with Germany nearly exclusively (96\%) with Target claims booked in the Bundesbank's balance sheet. It transferred hardly any marketable claims in net terms in exchange for the net flow of real resources and services that were delivered to them from Germany. In fact, even the tiny remainder of $4 \%$, or 9 billion euros, can partly be explained by Germany's intergovernmental aid to Greece (6 billion euros in 2010).

\footnotetext{
${ }^{31}$ Deutsche Bundesbank, Time series database, series EC1804, accessed on 15 November 2011.
} 
Figure 11: Annual current account balances

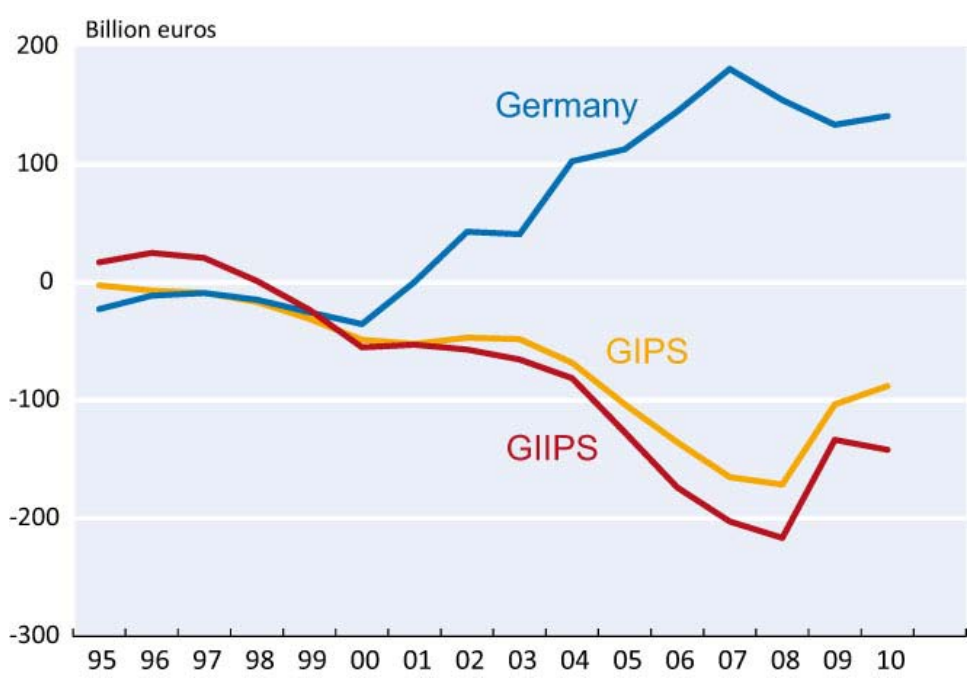

Source: Eurostat, Database, Economy and Finance, Balance of Payments Statistics, Balance of Payments by Country; calculations by the authors.

As the time path of Germany's Target claim is closely negatively correlated with the GIPS countries' Target liability (Figure 2) and a similar correlation holds between Germany's and the GIPS countries' current account (Figure 11), one might be tempted to assume that both the Target credits and the trade figures result from a bilateral relationship between Germany and the GIPS. Such is not the case, however. After all, only 5\% of Germany's exports go to these countries. The current account and Target balances rather show the inflows from, and outflows to, big markets to which many countries are linked. Thus, for example, it would have been possible that Greek buyers of French products paid with newly printed money they borrowed from the Greek NCB rather than from a private Italian bank, because the Italian bank, which used to finance such deals, preferred to invest its funds in Germany rather than continue lending it to Greece. In this case, neither the French nor the Italian Target balances would have changed, while the Greek central bank would have developed a Target deficit and the Bundesbank a Target surplus. Nevertheless, it would have been the Bundesbank that financed the Greek import of French goods with part of the funds that Germany's export surplus generated. That is not only what the balance sheets of the German and Greek central banks would show, but it also follows from the fact that the Greek NCB's refinancing credit would be growing at the expense of that of the Bundesbank.

Figure 12 illustrates the extent to which the GIPS current account deficits were financed with Target credits, i.e. with the printing press. It compares the time series of the accumulated current account deficits of the GIPS countries (upper curve) with the time series of their Target liabilities (lower curve), familiar from Figure 2. The starting point of the upper curve has been shifted to the value of the Target debt by the end of 2007, to be able to compare the accumulated sum of current account deficits with the accumulated sum of Target deficits (the increase in the Target debt) since this point in time. The small coordinate system starting at that point measures the accumulated balances on both accounts. According to the above equations, the vertical distance between the two curves equals the accumulated normal capital imports (not including the public credit provided via the ECB system). 
Figure 12: Financing the GIPS current account deficits via the Target system (Dec. $2002-$ June 2011; excluding Italy)

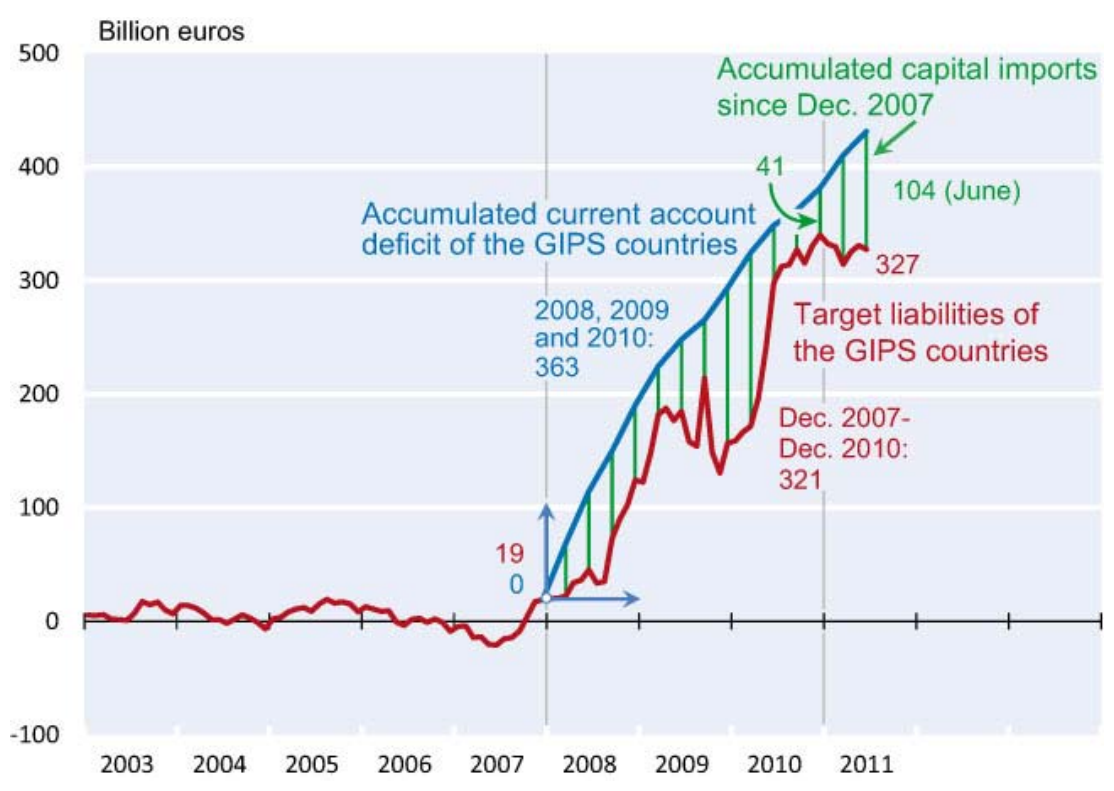

Note: The ordinate shows the Target liability of the GIPS, not including Italy. It contains a further auxiliary coordinate system starting on the Target curve by the end of 2007 to measure the accumulated current account and Target deficits respectively.

Sources: See Appendix; Eurostat, Database, Economy and Finance, Balance of Payments Statistics, Balance of Payments by Country; National statistical agencies; calculations by the authors.

As to the interpretation of the two curves, note that they both measure stocks rather than flows. The flows, i.e. the current account deficits and the Target deficits (the annual change in the Target liabilities), are given by the slopes of the two curves. Obviously, these slopes are not closely correlated over time. Until spring 2009 the slopes were similar, indicating that the current account deficits were financed with Target credits, with no private capital flows contributing to their financing. Then, from spring 2009 to autumn 2009, private capital flowed again, even reducing the Target stocks: more capital was temporarily coming in than needed to finance the current account deficits. However, in autumn 2009 the capital markets again became jittery and shied away from the GIPS. From then through to the end of 2010 the Target deficits exceeded the current account deficits, accommodating a private capital flight from the GIPS to other countries of the Eurozone.

Obviously, there was no statistical correlation between the Target and current account deficits. Still, as can be seen from the final positions of the two curves by December 2010 and as was mentioned above, over the entire period Target credit did finance $89 \%$ of the aggregate current account deficit of the GIPS. Only $11 \%$ of that deficit was financed with ordinary net capital imports (including the rescue funds since May 2010).

Note that this is a descriptive statement about a statistical fact that stems from the official accounting systems and not a theoretical or econometric claim, projection or hypothesis, as some of our critics had presumed. ${ }^{32}$ If a dual-fuel car engine can run on both gasoline and natural gas, saying that $89 \%$ of its energy consumption in a particular period was delivered by gasoline implies that only $11 \%$ came from natural gas. It does not imply that there is a statistical correlation between the energy consumption in general and the gasoline

\footnotetext{
${ }^{32}$ On this, see point 1 in the Reply to the Critics in the Appendix to Sinn and Wollmershäuser (2011).
} 
consumption in particular, because that correlation depends on how often the driver switches between the two fuels.

Let us now dig deeper into the issue by looking at the GIPS countries one by one, and now including Italy. Figure 13 gives an overview of the details. The single charts show basically the same kind of graphs as those depicted in Figure 12, but they break the information down to the single countries. Again, the vertical distance between any pair of curves shows the net capital import (current account curve above Target curve) or net capital export (current account curve below Target curve) accumulated since the end of 2007, respectively.

It is easily apparent that an approximate equality between the accumulated current account deficit and the Target debt only existed for Greece and Portugal. In these countries, the sum of the ordinary capital flows during the years 2008, 2009 and 2010 was nearly zero. As of December 2010, in Greece 91\% of the current account deficit accumulated in these three years, and in Portugal 94\%, was financed with Target credits. As private capital shied away, the two countries financed almost their entire current account deficits with the printing press. Allowing this to happen by reducing its collateral requirements meant indeed, as was argued above, that the ECB had put together a rescue program well before the official rescue programs.

For Ireland and Spain things were quite different, and in both directions. Spain evidently was still able to attract private capital to finance its current account deficit, so that the Spanish NCB only had to help out sporadically to pay for the excess imports. Total Target liabilities during the three years only increased by 46 billion euros, while the accumulated current account deficit came to 206 billion euros.

The opposite occurred in Ireland. Ireland was affected by a massive capital flight, reflected in the fact that its cumulative current account deficit over the three years was only 14 billion euros, while its Target liabilities over the same period rose by 145 billion euros (to 142 billion euros). That was almost as much as Ireland's annual GDP, which recently amounted to 156 billion euros. In proportion to its size, the country has a gigantic banking system. For this reason, after the Lehman collapse in 2008 the government provided guarantees to the country's banks amounting to two-and-a-half times the nation's GDP. ${ }^{33}$ These guarantees, however, evidently did not restore confidence. The banks and the other capital market operators that had congregated in Ireland decided to withdraw their capital from the country; they did this by selling their assets to the Central Bank of Ireland, either directly or indirectly via other banks, and seeking a safe haven for their cash elsewhere. At the same time, the commercial banks in other European countries either refused to provide further credit to the Irish banks or only at extremely high interest. The Central Bank of Ireland acted, in this case, as a lender of last resort, stepping into the breach and cranking up its moneyprinting machine.

\footnotetext{
${ }^{33}$ See Sinn (2010a, p. 193).
} 
Figure 13: Current account and Target balances in detail (Dec. 2002 - September 2011)
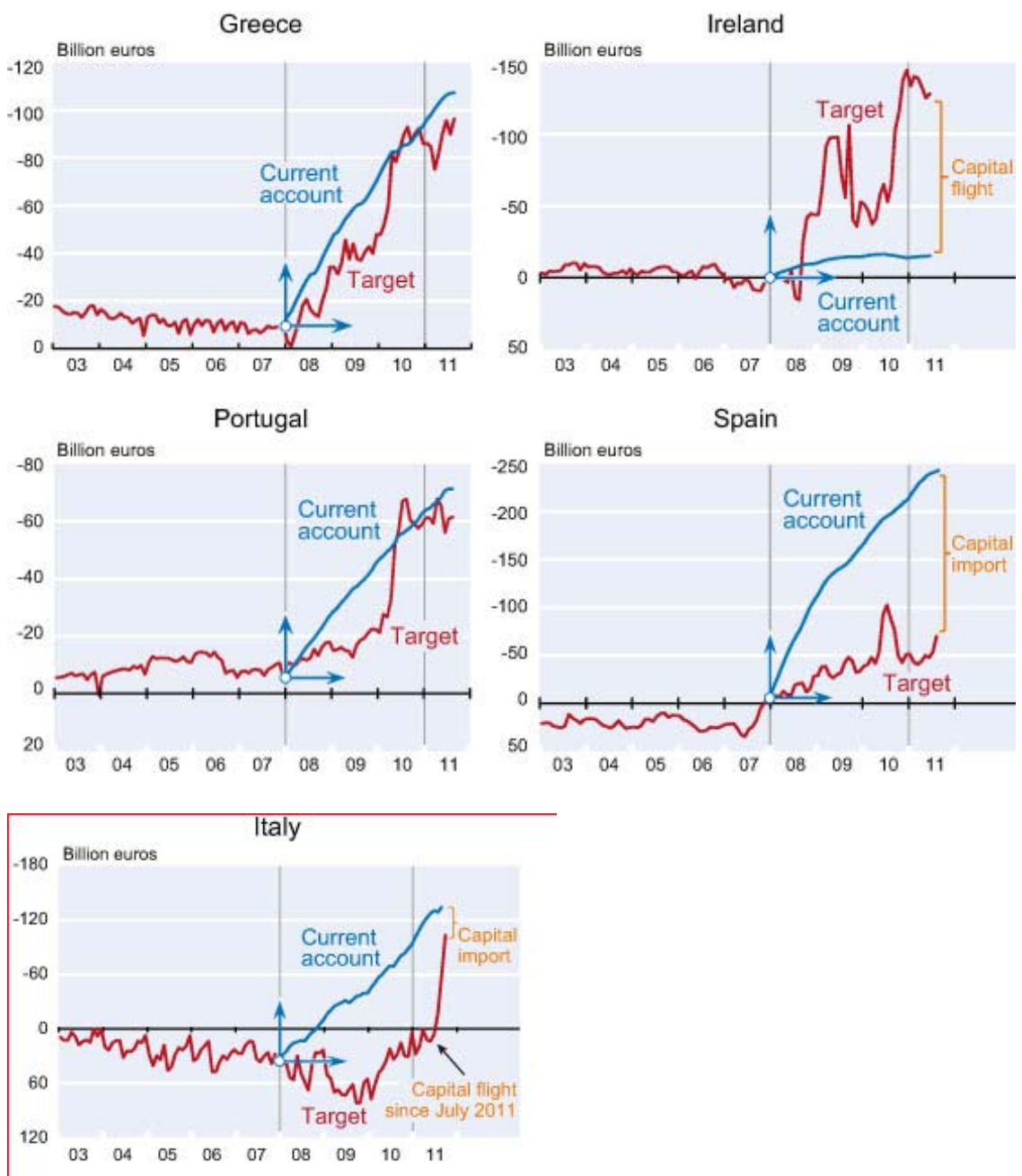

Notes: The Central Statistics Office Ireland only publishes quarterly current account data. Since the latest data available is from Q2 2011, for Ireland the chart ends in June 2011. For Portugal, Spain and Greece the charts end in August 2011. In the case of Italy, the last current account data stem from August, and the Target data extend to September.

Sources: See Figure 12.

The last chart in Figure 13 refers to Italy. Obviously, scarcely any Target balances built up in 2008, 2009 and 2010. The Italian current account deficit during this period was chiefly privately financed, and until the autumn of 2009 Italy even enjoyed capital imports beyond what was needed to finance its current account deficit, as shown by the fact that its Target liability became more and more negative while the curve showing the accumulated current account deficit was rising. Then, from autumn 2009 until the first half of 2011, the Target curve changed its slope, and became roughly as steep as the current account curve, indicating that Italy did not enjoy further capital imports to finance its current account deficits, but used the printing press instead. However, Italy started from having a stock of Target claims, and was able to draw from this stock until July 2011, when the stock ultimately changed sign and turned into a liability. In August and September, the liability even increased progressively, since all of a sudden a huge capital flight had got under way, whose momentum is unbroken at this writing and which seems to be quickly consuming the stock of net capital 
imports built up in 2008 and 2009. In fact, while the Italian current account deficit was just 5.4 billion euros in August, the country's Target balances deteriorated by 41 billion euros in that single month.

In a smaller measure, capital flight also occurred in Greece, even though the two curves nearly coincide by the end of the year 2010. The reason is that in 2010 Greece enjoyed an intergovernmental rescue credit on the order of 31.5 billion euros, which in itself reduced the Target liability. The fact that the accumulated Target deficit over the three years considered nevertheless stayed below the respective current account deficit by only 7.4 billion euros indicates that in net terms there must have been a private capital flight from Greece on the order of 24.1 billion euros.

While it is clear that the Target credit and other rescue operations have financed the current account deficits and the capital flight, they may, in fact, even have caused or supported them. After all, had the public credit channels not been available, there would have been an even stronger credit squeeze in the GIIPS countries, which would have made it impossible for them to finance their current account deficits. A rapid nominal contraction of the economy would have depressed the nominal incomes and hence imports, avoiding the current account deficits. Moreover, private capital owners would not have been able to flee if the banking sector had been unable to buy their assets with the newly printed money it was able to borrow from its NCB. Asset prices would have fallen rapidly, and an equilibrium would have emerged which would have made it again sufficiently attractive for capital to stay or for new capital to come from abroad. True, quite a number of investment funds, banks and insurance companies in the rest of the world would have suffered from write-off losses, and states would have had to rescue a number of commercial banks. However, this would have been a feasible alternative to a policy that in the end may turn out to merely have protected wealth owners from capital losses and have maintained an unsustainable vector of relative prices that requires permanent financing - a bottomless pit.

\section{Target Balances in the United States}

The possibility of taking on Target loans at the ECB interest rate distinguishes the Eurosystem sharply from the US Federal Reserve System, whose Target analogue is called "Interdistrict Settlement Account". While that system does allow for Target-like balances resulting from the creation of outside money, i.e. money used for acquiring a net inflow of goods and/or assets from other districts, it has never experienced excessive flows comparable to those now taking place in the Eurozone as a result of the European sovereign debt crisis, wiping out the refinancing credit in its sub-districts and making the local central banks net borrowers of central bank money. As far as we know, Target-like problems never were an issue in US history. This is reason enough to go into the details and try to understand what factors might have been responsible for this.

In the US, payment transactions are done via the Federal Reserve Wire Network (short: Fedwire) and operate in principle in a manner quite similar to that in the Eurozone. For historical reasons the US currency area is divided into 12 Federal Reserve districts, whose borders are not identical with the borders of the federal states. ${ }^{34}$ As a rule, the districts comprise several states, and in some instances a state may form part of two Federal Reserve districts. The sizes of the districts was fixed at the time the Federal Reserve System was founded in 1913 and depended on the distribution of the population at the time, and they are roughly comparable to those of the 17 states of the Eurozone. However, unlike the Eurozone's

\footnotetext{
${ }^{34}$ See Ruckriegel and Seitz (2002).
} 
NCBs, which are state-owned institutions, the regional Federal Reserve Banks, in short "District Feds", are private institutions, belonging to the respective districts' commercial banks.

Each District Fed is responsible for the operational implementation of monetary policy in its area. Payments between commercial banks of different districts are done via the Fedwire System and are settled via the accounts of the commercial banks at the corresponding District Fed. The payments are booked in the Interdistrict Settlement Account, a real-time gross settlement system like the European one.

Despite the similarities between the two systems, there are several important differences. ${ }^{35}$ First, the Fedwire System is a multilateral system of accounts in which each District Fed has a settlement account vis-à-vis each of the eleven other District Feds. As in the Eurosystem, the District Fed has to carry out payment orders from other districts and is assigned compensating claims that are shown in its balance sheet. A compensating claim is, however, not held against the entire central bank system, but against the respective District Fed that ordered a payment. While no interest is accrued from the claims or paid on liabilities within a year, the Interdistrict Settlement Account of the District Feds must be settled in April of each year with marketable assets. ${ }^{36}$ As in Europe, a District Fed does have the right to print more money to finance a net acquisition of assets or goods from other districts. But instead of simply booking a liability in its balance sheet and paying the main refinancing rate, it must hand over tangible assets to redeem its debt. Technically, this is done by the Fed by varying the ownership shares in a clearing portfolio of marketable and interest-bearing assets that it supervises on behalf of the District Feds.

According to the official statements of the Federal Reserve, the assets whose ownership shares are transferred are gold certificates. Gold certificates are securities collateralized by gold, issued by the US Treasury, that bear the right to be exchanged for gold on demand. ${ }^{37}$ They are safe, marketable securities, which cannot be created by the District Fed itself.

However, when a policy of credit easing was adopted during the crisis, this practice was abandoned and US Treasury securities were permitted for settling the balances, accepting in the end even mortgage-backed securities. This still does not make the US system similar to the European one, though. For one thing, the ownership title refers to tangible assets that retain their value even if the District Fed that created the outside money flowing to other districts goes bankrupt. And for another, the assets concerned earn the market rate of interest for the respective risk category. ${ }^{38}$

If such a system were introduced in the Eurozone, the NCBs of the GIIPS would no longer have an interest in overexerting their money-printing presses in order to satisfy their internal credit demand, since there would be no advantage to such a policy over a direct financing of liquidity needs through the capital market. In either case must marketable debt instruments bearing the normal rate of interest be turned over if the required liquidity is to be obtained. As in the US, no Target balances would be piling up.

\footnotetext{
${ }^{35}$ See Garber (2010).

${ }^{36}$ Payments are done only for deviations from average. If, for example, a regional Federal Reserve Bank A has accumulated claims on another Federal Reserve Bank B, these claims are reduced by the average balance of the Interdistrict Settlement Account of the past 12 months.

${ }^{37}$ In 1934 the entire gold stock of the Federal Reserve Banks was transferred to the US Treasury (Gold Reserve Act of 30 January 1934). In return the Federal Reserve Banks received gold certificates that bear the writing: "This is to certify that there are on deposit in the Treasury of the United States of America dollars in gold, payable to bearer on demand as authorized by law." Since that time no gold certificates have been issued and the Federal Reserve Banks no longer own gold of their own. See Woelfel (2002).

${ }^{38}$ In the discussions about the construction of the Eurosystem Reeh (1999, p. 24) had proposed to charge the market rate of interest for internal Eurozone imbalances.
} 
However, the implication of doing so would be that the Bundesbank, based on the September 2011 figures, would have the right to receive marketable assets on the order of 450 billion euros from other Eurozone NCBs. If the other NCBs had to pay the Bundesbank with assets they do not have, this could pose an unbearable hardship for some of them, driving them into bankruptcy overnight and destroying the Eurosystem. The situation would be quite similar to 1968, when General De Gaulle hastened the demise of the Bretton Woods system by sending warships to the US to convert the dollar claims of the Banque de France, the equivalent of the Bundesbank's Target claims, into gold from Ford Knox. Thus, a grandfathering rule would be useful for a conversion of the existing Target claims, stretching the US-like payment with marketable assets over considerable periods of time.

For the time being, the debtor NCBs could at least secure their Target liability by handing over the collateral they received from their private banks when lending out the newly printed money. However, due to the low quality of this collateral and the fact that the interest on the collateral belongs to the private banks that provided it, this would not eliminate the incentive to solve their payment difficulties with the printing press. To ensure that the Target loans are not more attractive for the debtor NCBs than market loans, not only collateral must be provided, but marketable assets including their interest would have to be handed over to the creditor NCBs to redeem the Target debt. Alternatively, the collateral solution could be combined with the debtor NCBs paying to the creditor NCBs a premium interest rate above the ECB's main refinancing rate, as proposed by ex-Bundesbank President Helmut Schlesinger (2011).

In view of the political tour de force that would be necessary for such solutions in Europe, the question arises of whether the problem of overflowing Target loans could not be solved by milder policy options. For example, a return to higher collateral demands for the refinancing operations would surely result in less central bank credit being granted in the GIIPS countries. This would indeed have the desired effects if the collateral standards were set high enough. The problem with such a measure, however, is that it cannot be implemented credibly, as in any halfway-serious crisis the European Central Bank Council will again tend to ease its collateral standards, given that the countries benefiting directly and indirectly from such policy hold the majority in it. The problem is well-nigh impossible to solve under the current one-country one-vote system of the European Central Bank Council.

A similarly pessimistic argument applies to a possible renunciation of the fullallotment policy. Even if the ECB were to limit the money supply by returning to the precrisis variable-rate tenders, it would not be able to prevent the least solid commercial banks from making the highest interest-rate offers because anything they offer is more favorable than the excessively high interest rates they have to offer private lenders. A sort of Gresham's law would therefore operate, shifting the credit to the most risky banks in Europe whose collateral just manages to comply with the collateral standards set by the ECB. ${ }^{39}$ The lion's share of the central bank credit would therefore still be created in the GIIPS countries.

Thus, Europe might wish to think about adopting the US rules about running a monetary union. After all, these rules have been distilled from a long historical trial-and-error process and have been shown to function. It is not always necessary to re-invent the wheel.

\footnotetext{
${ }^{39}$ See Chailloux, Gray and McCaughrin (2008).
} 


\section{Conclusions}

This paper has tried to shed light on the European balance-of-payments crisis by drawing on a hitherto little known accounting system embedded in a non-transparent way in the balance sheets of the Eurozone's National Central Banks (NCBs): the Target balances. While Target balances at first glance seem to be inconsequential technicalities of an interbank settlement system, we demonstrate that they indeed measure the Eurozone's internal balance-ofpayments surpluses and deficits, and hence capital flows and credit shifts through the ECB system. In our opinion the Target statistics provide the most accurate seismograph of the shockwaves that were sent through the Eurozone during the global financial crisis.

The Target data show that the Eurozone until 2010 built up extremely large distortions in the balances of payments among the euro countries that raise deep questions about its viability. By September 2011, the accumulated payment imbalance between Germany and the rest of the Eurozone had grown to 450 billion euros.

During the financial crisis, an increasing share of the Eurozone's stock of central bank refinancing credit has gradually been relocated from the core to the periphery to compensate for the now low or inexistent private capital flows to the periphery that used to cover its current account deficits and also for outright capital flight from there to the core. In the meantime, the Eurosystem's entire stock of net central bank credit has been relocated to the periphery, and the core's NCBs have become net borrowers of central bank money, sterilizing the huge inflow of money that has been printed and lent out by their partners in the periphery. While the printing presses in the periphery overheat, the printing presses in the core have been converted to money shredders.

We showed that the current account deficits of Greece and Portugal were almost entirely financed by Target credits in the years 2008 - 2010, and Ireland in addition accommodated a major capital flight that way, a policy that Italy copied in the summer of 2011. Germany, on the other hand, in the period 2008 - 2010, was paid for its 264-billioneuro current account surplus with the rest of the Eurozone almost entirely (96\%) with Bundesbank Target claims on the ECB. No marketable assets were returned. Currently, there is a huge capital flight from Italy to Germany that even results in swapping German marketable assets for Target claims.

These are all symptoms of a deep balance-of-payments crisis that resembles in many respects the fatal crisis of the Bretton Woods system. The cheap credit that the euro made possible for the periphery countries led to inflationary bubbles and huge current account deficits, as in the USA during the Sixties. The deficits in Europe's periphery were first financed by private capital flows, but when the global financial crisis swept over Europe in 2007, capital shied away and the ECB stepped in by allowing the NCBs of the periphery to finance the deficits with the money-printing press, just as the Fed had done before the breakdown of the Bretton Woods system. And in the same way as the dollars that in that system flowed from America to Europe were converted into European currencies and crowded out the central banks' refinancing credit, the extra money recently printed in the Eurozone's periphery flowed to the core's NCBs and crowded out the refinancing credit there. By relocating refinancing credit from the surplus to the deficit countries, public capital flowed through the Eurosystem and replaced private capital flows. Under the Bretton Woods system, this process of shifting the refinancing credit proved unsustainable and a balance-of-payments crisis resulted, which finally led to the collapse of the system.

The European system may not collapse as quickly as the Bretton Woods system did, given that the Bundesbank, which has accumulated Target claims instead of dollar claims, will be unable to follow General De Gaulles's example and convert its claims into gold. After all, its Target claims are intangible assets that cannot be converted into anything without a fundamental change in the ECB's policy. Thus, year after year, the periphery's current 
account deficit and capital flight may continue to be financed with the printing press, and the core can continue to shred the money flowing in as payment for goods and assets sold to the periphery. The peripheral countries and the core countries, above all Germany, can just go on swapping Target claims for real marketable assets that the inhabitants of the periphery buy in the core.

However, one can doubt whether such a solution would really be sustainable. There are too many cumbersome aspects that would undermine its economic and political feasibility.

First, the exhaustion of the stock of refinancing credit may handicap the transmission of the ECB's monetary policy decisions. By setting its own lending rate (main refinancing rate) the ECB used to affect interbank lending rates and influenced the commercial banks' interest rates for new loans to firms and private households. That way it used to control and steer the Eurozone's economy. Today, however, as banks of the core countries mostly abstain from participating in the ECB's refinancing operations and lend money to the ECB instead, the ECB's lending rate no longer is able to directly affect the interbank lending rate in the core. That rate now is just a short-term rate for risky banks with dubious collateral located in the periphery, and apart from that there is a well-functioning interbank market between safe banks in the core with an interest rate that falls short of the ECB's lending rate.

Second, as commercial banks in the core lend to the ECB, while the monetary base remains unchanged, they nevertheless become more and more liquid. After all, they can withdraw their deposit facilities with the ECB at any time and convert them to true central bank money on demand. And they can always use their time deposits with the ECB as collateral for private credit they can take in the market. Seen this way, it may be difficult if not impossible to effectively sterilize the liquidity effect of the money-printing going on in the periphery - despite the fact that neither the international distribution of euro base money nor its time path have changed during the crisis.

Third, the ongoing rescue operations, by activating the printing press, preserve the wrong set of prices for goods, labor and capital that resulted from the bubble created by the cheap credit that the euro offered in the early years of the crisis. They thus preserve the current account deficits of the periphery countries, and they also prevent the flight capital from returning because they create a permanent downward risk for asset prices. This reminds of the many ineffectual attempts to use central bank interventions to keep exchange rates away from their equilibrium values. These attempts have shown that gigantic intervention funds are necessary and that the central banks may still be the losers in the end. ${ }^{40} \mathrm{With}$ regard to exchange rates, central banks have learned by now that it is futile to defend wrong prices for ever. It remains to be seen how long European politicians will need to heed that lesson.

The Target imbalances show that a system with idiosyncratic country risks and international interest spreads for public and private bonds is incompatible with a monetary system that allows countries to finance their balance-of-payments deficits with the printing press, without having to pay for the extra money-printing with marketable assets as is the case in the USA. Such a system will always induce the less-solid countries to draw Target credit to avoid the risk premium that the market demands, leading them eventually to a balance-ofpayments crisis. To avoid this problem, Europe has only two options. Either it socializes national debts in order to eliminate the international differences in interest rates (by creating a uniform default risk for all countries), limiting excessive borrowing through the imposition of politically mandated constraints. Or it ensures that the Target balances are paid annually with

\footnotetext{
${ }^{40}$ One of the most impressive lessons was the fight of the Bank of England against George Soros's short-selling in 1992. At the time, the Bank of England had tried to support the pound sterling by selling dollars, deutschmarks and francs out of its stocks. It lost the battle, because George Soros had calculated the size of the foreign currency reserves of the bank and knew how many pounds sterling he had to sell short in order to win over the Bank of England. He won, the pound sterling had to be devalued, and Great Britain failed to meet the entrance conditions for the European Monetary Union.
} 
marketable assets, keeping the debt burdens within the national responsibility and allowing for country defaults and interest differentials.

The US obviously chose the second route. States can go bankrupt, excessive capital flows are prevented by state-specific interest spreads, and the Target balances are unattractive, since they have to be settled with marketable assets. This system is stable, because it avoids excessive capital flows between the states and thus excessive US-internal trade imbalances. By contrast, Europe is currently drifting in the other direction. On the horizon a system can be divined where states are protected from bankruptcy, Eurobonds eliminate interest spreads, political constraints are to limit excessive capital flows, and the right to cover balance-ofpayment deficits with the printing press is undisputed. Arguably, this system will be vulnerable to political pressure and manipulation by the debtor countries, even if Europe finds the strength to eliminate local fiscal autonomy and create a fiscally unified nation state.

In our opinion, the reason why Europe is drifting in the direction of Eurobonds lies in the path-dependence resulting from the prior decision to set up a Eurosystem that provides the right to settle balance-of-payments deficits by creating money without having to pay for the extra money creation with marketable assets. This decision has provided a sufficiently generous self-service rescue facility to render the public Eurozone rescue facilities that have subsequently been set up dispensable for the first phase of the crisis, and this system is in principle still available today as a fall-back option to the public rescue programs, even though the ECB's switch to a net-debtor position signals that it may be running out of ammunition. If the distressed countries do not receive help or do not deem the rescue operations offered to them generous enough, they always have the option of printing the money they need and lending it via their commercial banks to the private sector or to the government. ${ }^{41}$ True, they need a majority in the ECB council to lower the collateral requirements sufficiently or to allow ELA credits to be issued, for which no collateral is necessary. However, they have evidently been able to put together such a majority in the past, and they may be able to do so in the future. Arguably, the potential threat with the printing press in the basement has made it easier for them to convince their European partners to solve their balance-of-payments crises with generous public rescue operations rather than undergoing the hardship of solving such crises by lowering the bubble-driven prices of labor, goods and assets to their equilibrium levels.

\footnotetext{
${ }^{41}$ A good example for this is Ireland. Although this country had a massive balance-of-payments crisis, it was reluctant to seek shelter under the Eurozone's EFSF rescue umbrella in autumn 2010. It had to be pushed hard by ECB President Trichet before it finally moved. This reluctance can be explained by the fact that the ECB Target credit at that time levied only $1 \%$ in interest, while Ireland had to pay 5,8\% for the EFSF credit offered to it. Ireland later succeeded in lowering the interest rate for the EFSF credit to only $3.8 \%$ in renegotiations finalized in July 2011.
} 


\section{Acknowledgments}

We thank Jürgen Gaulke, Marga Jennewein, Michael Kleemann, Paul Kremmel, Wolfgang Meister, Beatrice Scheubel, Heidi Sherman and Christoph Zeiner for technical support and Julio Saavedra for helping polish our English and posing good questions. We also thank Michael Burda, Mario Draghi, Otmar Issing, Georg Milbradt, Helmut Schlesinger, Christian Thimann, Gertrude Tumpel-Gugerell, Jean-Claude Trichet and Martin Wolf for in-depth conversations, without implying in any manner whatsoever that they adhere to our arguments. We thank the participants of a press briefing on 22 June 2011 in Frankfurt for valuable comments. For useful comments on this paper we thank Wilhelm Kohler, Thomas Mayer, Jim Poterba, Alfons Weichenrieder and Frank Westermann. 


\section{References}

Banca d'Italia (2011), Supplements to the Statistical Bulletin, Vol. XXI, 6 October.

Beise, M. (2011), "Die Wahrheit über den Euro," Süddeutsche Zeitung, 9 April, p. 23.

Brendel, M. and C. Pauly (2011), "Auf schmalem Grat," Der Spiegel, 23 May, p. 60.

Chailloux, A., S. Gray, and R. McCaughrin (2008), "Central Bank Collateral Frameworks:

Principles and Policies," IMF Working Paper No. 222.

Deutsche Bundesbank (2011a), "TARGET2-Salden der Bundesbank," Press release of 22

February 2011.

---- (2011b), Annual Report 2010, Frankfurt.

----- (2011c), "The Dynamics of the Bundesbank's TARGET2 Balance," Monthly Report, March, p. 34-35.

----- (2011d), Balance of Payments Statistics, September 2011.

European Central Bank (2010), The Payment System - Payments, Securities and Derivatives, and the Role of the Eurosystem, Frankfurt.

(2011a), Target Annual Report 2010, Frankfurt.

(2011b), "TARGET2 Balances of National Central Banks in the Euro Area," Monthly Bulletin, October, p. 35-40.

European Economic Advisory Group (2011), A New Crisis Mechanism for the Euro Area, in: European Economic Advisory Group (ed.), The EEAG Report on the European Economy, Munich, p. 71-96.

Feldstein, M. (1997), "The Political Economy of the European Economic and Monetary Union: Political Sources of an Economic Liability," The Journal of Economic Perspectives 11, p. 23-42.

Fischer, M (2011), "Große Summen," Wirtschaftswoche, 28 February, p. 26.

Friedman, M. (1962), Capitalism and Freedom, Chicago.

---- (1997a), "Why Europe Can't Afford the Euro - The Danger of a Common Currency," The Times, 19 November.

---- (1997b), "Ich sage, der Euro wird bald wieder auseinanderbrechen," Die Presse, 12

December, p. 23.

----- (2001), "Auf Kosten Dritter," Capital, 11 July, p. 18.

Fuest, C. (2011), "Die EZB ist zu weit gegangen," Handelsblatt, 15 June, p. 56.

Garber, P. M. (1989), "Notes on the Role of Target in a Stage III Crisis," NBER Working Paper 6619.

----- (2010), "The Mechanics of Intra Euro Capital Flight," Deutsche Bank Economics Special Report.

Gurley, J.G. and E.S. Shaw (1960), Money in a Theory of Finance, Washington, D.C.

Handschuch, K. (2011), "Versteckte Krisenhilfe," Wirtschaftswoche, 21 February, p. 8.

Hawkins, J. (2003), Central Bank Balance Sheets and Fiscal Operations, in: Bank for International Settlements (ed.), Fiscal Issues and Central Banking in Emerging Economies, Basle, p. 71-83.

Homburg, S. (2011), "Anmerkungen zum Target2-Streit," ifo Schnelldienst 64, No. 16, 31 August, p. 46-50.

ifo Institut (2011), "Die europäische Zahlungsbilanzkrise," ifo Schnelldienst 64, No. 16, 31 August, p. 3-94, with contributions of H.-W. Sinn, H. Schlesinger, W. Kohler, C. B. Blankart, M. J. M. Neumann, P. Bernholz, T. Mayer and J. Möbert and C. Weistroffer, G. Milbradt, S. Homburg, F. L. Sell and B. Sauer, I. Sauer, J. Ulbrich and A. Lipponer, C. Fahrholz and A. Freytag, U. Bindseil and P. Cour-Thimann and P. König, F.-C. Zeitler, K. Reeh, http://www.cesifogroup.de/portal/pls/portal/docs/1/1209833.PDF 
Klepsch, C. and T. Wollmershäuser (2011), "Yield Spreads on EMU Government Bonds How the Financial Crisis Has Helped Investors to Rediscover Risk," Intereconomics / Review of European Economic Policy, No. 46, p. 169-176.

Kohler, W. (2011), "Zahlungsbilanzkrisen im Eurosystem: Griechenland in der Rolle des Reservewährungslandes?," ifo Schnelldienst 64, No. 16, 31 August, p. 12-19, http://www.cesifo-group.de/portal/pls/portal/docs/1/1209726.PDF.

Krugman, P. (2010), "The Euro Trap," New York Times, 29 April.

http://www.nytimes.com/2010/04/30/opinion/30krugman.html?ref=paulkrugman.

----- (2011), "The Euro Living Dangerously," NY Times Blog, 1 June.

http://krugman.blogs.nytimes.com/2011/06/01/the-euro-living-dangerously/.

Krumrey, H. (2011), "Am Bundestag vorbei," Wirtschaftswoche, 28 February, p. 26.

Mayer, T. (2011), "Euroland's Hidden Balance-of-payments Crisis", Deutsche Bank Research, 26 October 2011.

Reeh, K. (1999), Zahlungsbilanzausgleich in der Währungsunion. Viele Frage, aber noch keine Antworten, in: H.-J. Stagermann and O. Steiger (eds.), Herausforderung der Geldwirtschaft, Marburg, p. 295-328.

---- (2001), Das Eurosystem: Von einem Behörden- zu einem Bankensystem?, in: H. Schmidt, E. Ketzel, and S. Prigge (eds.), Wolfgang Stützel - moderne Konzepte für Finanzmärkte, Beschäftigung und Wirtschaftsverfassung, Tübingen, p. 333349.

Ruckriegel, K and F. Seitz (2002), "The Eurosystem and the Federal Reserve System Compared: Facts and Challenges," ZEI Working Paper No. B02.

Ruhkamp, S. (2011), "Misstrauen lähmt den Geldverkehr," Frankfurter Allgemeine Zeitung, 19 April, p. 11.

Seitz, F. (1995), "Der DM-Umlauf im Ausland," Deutsche Bundesbank Diskussionspapier $1 / 95$.

Schlesinger, H. (2011), "Die Zahlungsbilanz sagt es uns," ifo Schnelldienst 64, No. 16, 31 August, p. 9-11.

Sinn, H.-W. (2010a), Casino Capitalism. How the Financial Crisis Came about and What Needs to Be Done Now, Oxford University Press, Oxford.

----- (2010b), "Nachweisbare Wirkung," Wirtschaftswoche, 7 June, p. 39.

---- (2010c), "Reallocation of Savings in Europe," ifo Viewpoint, 115, 22 June, http://www.cesifo-group.de/portal/page/portal/ifoHome/Bpolitik/05stp/_stp?item_link=stp115.htm.

----- (2010d), "Rescuing Europe," $\bar{C}$ ESifo Forum, Special Issue, August. http://www.cesifogroup.de/DocCIDL/Forum-Sonderheft-Aug-2010.pdf.

----- (2011a), "Neue Abgründe," Wirtschaftswoche, 21 February, p. 35. http://www.cesifogroup.de/link/_echomitarb/ifostimme-wiwo-21-02-11.htm.

---- (2011b), "Deep Chasms," ifo Viewpoint, 122, 29 March, http://www.cesifogroup.de/portal/page/portal/ifoHome/B-politik/05stp/_stp?item_link=stp122.htm.

----- (2011c), "Tickende Zeitbombe," Süddeutsche Zeitung, 2 April, p. 24. http://www.cesifogroup.de/link/_echomitarb/ifostimme-sz-2011-04-03.htm.

----- (2011d), "The ECB's Secret Bailout Strategy," Project Syndicate, 29 April, http://www.project-syndicate.org/commentary/sinn37/English.

----- (2011e), "Die riskante Kreditersatzpolitik der EZB," Frankfurter Allgemeine Zeitung, 4 May, p. 10. http://www.cesifo-group.de/link/_echomitarb/ifostimme-faz-04-0511.htm.

----- (2011f), "Die heimlichen Kredite," Handelsblatt, 6 May, p. 72. http://www.cesifogroup.de/link/_echomitarb/ifostimme-hdbl-06-05-11.htm.

----- (2011g), "Target-Salden, Außenhandel und Geldschöpfung," ifo Schnelldienst 64, No. 09, 13 May, p. 23-25, . 
----- (2011h), "The ECB's Stealth Bailout," VOX, 1 June. http://www.voxeu.org.index.php?q=node/6599.

----- (2011i), "Das unsichtbare Bail-out der EZB," Ökonomenstimme, 11 June, http://www.oekonomenstimme.org/artikel/2011/06/das-unsichtbare-bail-out-der$\mathrm{ezb} /$.

----- (2011j), "Eine Einladung zur Selbstbedienung," Handelsblatt, 14 June, p. 9. http://www.cesifo-group.de/link/_echomitarb/ifostimme-hdbl-14-06-11.htm.

(2011k), "On and off Target," VOX, 14 June. http://www.voxeu.org/index.php?q=node/6644.

---- (20111), "How to Rescue the Euro: Ten commandments," VOX, 3 October. http://www.voxeu.org/index.php?q=node/7059

Sinn, H.-W., T. Buchen, and T. Wollmershäuser (2011), "Trade Imbalances - Causes, Consequences and Policy Measures: Ifo's Statement for the Camdessus Commission," CESifo Forum 12, No. 1, Spring, p. 47-58, http://www.cesifogroup.de/portal/pls/portal/docs/1/1201880.PDF.

Sinn, H.-W. and H. Feist (1997), "Eurowinners and Eurolosers: The Distribution of Seignorage Wealth in EMU," European Journal of Political Economy 13, p. 665689.

Sinn, H.-W. and T. Wollmershäuser (2011), "Target Loans, Current Account Balances and Capital Flows: The ECB's Rescue Facility," CESifo Working Paper No. 3500, 21 June, http://www.ifo.de/portal/pls/portal/docs/1/1212000.PDF.

Tornell, A. and F. Westermann (2011), “Greece: The sudden stop that wasn't”, VOX, 28 September. http://www.voxeu.org/index.php?q=node/7033.

United States Treasury Department (2003), The Use and Counterfeiting of United States Currency Abroad, Part 2, Washington.

Whittaker, J. (2011), "Intra-eurosystem Debts," Lancaster University Management School, 30 March, http://www.lancs.ac.uk/staff/whittaj1/eurosystem.pdf

Woelfel, C. J. (2002), Encyclopedia of Banking and Finance, London.

Wolf, M. (2011), "Intolerable Choices for the Eurozone," Financial Times, 1 June, p. 9. 


\title{
Appendix: Data Sources for Target Balances
}

\author{
Time series from National Central Banks:
}

For Germany, Italy and Spain, the Target time series can be downloaded from the databases of the respective NCBs. ${ }^{42}$ All other data are calculated from IMF statistics as will be explained below.

Our procedure is basically the same as that used by the ECB itself. As the ECB revealed in its October 2011 publication on the Target data, it does not possess a reporting system of its own, but also constructs its data from the IMF statistics. It writes ${ }^{43}$ :

"There is no single database grouping together the TARGET2 balances of all NCBs, but an imperfect proxy can be calculated on the basis of the IMF's International Financial Statistics as the sum of the monthly series "net claims on the Eurosystem" minus the difference between "currency issued" (which represents an NCB's share in banknote issuance based on its share in the ECB's capital) and "currency put in circulation" (which is the actual amount of banknotes issued by an NCB)."

This is exactly the method we used in June 2011 in Sinn and Wollmershäuser (2011) for those NCBs that do not publish their Target balances directly, and that we also pursue here.

Even the published national Target data are often somewhat hidden in the balance sheets. Only the Spanish NCB publishes them explicitly under this name. In the case of the Bundesbank, for example, the Target balances are contained under the position "Other Assets" in the Consolidated Balance Sheet of its Monthly Report (Bundesbank database, series TUB618). For example, by the end of 2010, the figure for Other Assets amounted to 355.9 billion euros, whereas at the end of 2006 it had been only 24.8 billion. The Bundesbank's Annual Report breaks down these assets into more detail. In addition to the claims within the Eurosystem, which include the Target claims as well as the Bundesbank's participating interest in the ECB (i.e. its equity share) and the claims arising from the transfer of foreign reserves to the ECB, this involves coins, tangible and intangible fixed assets, other financial assets, off-balance-sheet instruments, revaluation differences, accruals and prepaid expenses, and sundry items. The Bundesbank claims within the Eurosystem at the end of 2006 were 18.3 billion euros, of which 5.4 billion were accounted for by Target claims and the rest by the Bundesbank's participating interest in the ECB and the claims arising from the transfer of foreign reserves to the ECB. The remaining positions in the Other Assets accounted then for 6.4 billion euros. At the end of 2010, the claims within the Eurosystem amounted to 337.9 billion euros, and the participating interest (including the transfer of foreign reserves) amounted to 12.3 billion euros, which translates into a Target balance of 325.6 billion euros. The remaining positions under Other Assets amounted then to 18 billion euros. In the case of Italy, the Target data can be inferred by a similar procedure from the published balance sheets.

Time series from the International Financial Statistics of the IMF:

For all remaining NCBs, which in the summer of 2011 accounted for about 50 per cent of the Target balances, we calculated a proxy for the Target balances with data from the IMF's International Financial Statistics. The 'Target claims' are computed as the difference between 'Net claims on Eurosystem' (IFS code xxx12e0szkm) and the 'Intra-Eurosystem claims related to banknote issuance'. The latter is calculated as the difference between 'Currency

\footnotetext{
${ }^{42}$ The Bank of Greece also publishes its Target balances in its monthly financial statements, which are however only available as pdf documents and cannot be downloaded as complete time series.

${ }^{43}$ European Central Bank (2011b, p. 37, footnote 5).
} 
issued' (IFS code xxx14a00zkm) and 'Currency put into circulation' (IFS code $\mathrm{xxx} 14 \mathrm{~m} 00 \mathrm{zkm}){ }^{44}$

Apart from the 'Target claims / liabilities' and the 'Intra-Eurosystem claims / liabilities related to banknote issuance', the position 'Net claims on Eurosystem' consists of 'Participating interest in the ECB' and 'Claims equivalent to the transfer of foreign reserves to the ECB', both of which are positive claims for all NCBs. Thus, our proxy for the Target 2 balances is biased upwards by the latter two positions. In other words, the true Target liabilities of the crisis countries may even be a bit larger than those we report. However, this bias should be almost constant over time since these two positions only change, as a general rule, when the Eurosystem's capital key is modified or when the ECB's capital is raised. In the case of the Bundesbank, where we have both the actual Target 2 data from the Bundesbank database and the proxy calculated on the basis of the IMF data, Figure 14 shows that this bias is indeed almost constant over time and currently amounts to 11 billion euros. Since we are mainly interested in the change of the Target balances over time (above all since the outbreak of the financial crisis), the measurement error should leave our interpretation of the Target balances in the main text unaffected. We repeat that this is only meant to demonstrate the measurement procedure we used for some of the other Eurozone countries for which we do not have balance sheet data. The data for Germany, Italy and Spain that we use in this paper all stem directly from the balance sheets of the respective NCBs and are no proxies.

Figure 14: Measurement error - excess of IMF proxy for German Intra-Eurosystem claims over actual Bundesbank data

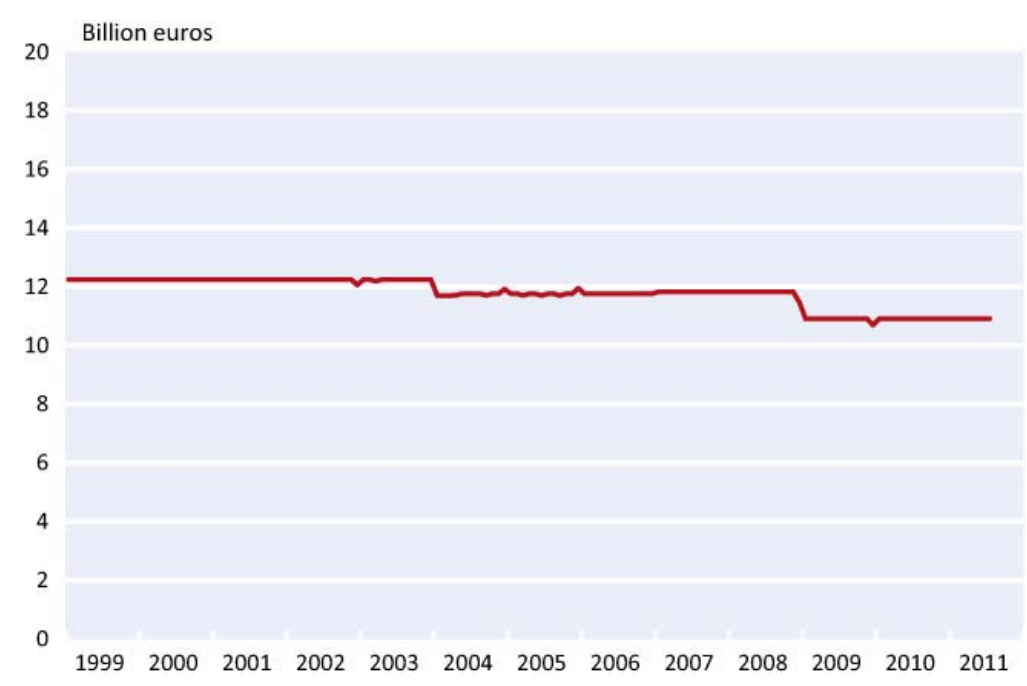

The Target balance for the ECB including claims of non-Eurozone NCBs on the Eurosystem is calculated as a residual, based on the assumption that the sum of all balances (calculated on the basis of the IMF's International Financial Statistics) should equal zero.

\footnotetext{
44 'Currency put into circulation' is the actual value of banknotes issued by an NCB. 'Currency issued' refers to the statutory value of banknotes that is booked on the liability side the NCB's balance sheets and that is calculated as a fixed share of the total value of banknotes issued by the Eurosystem as a whole. The share is equal to the NCB's share in the ECB's capital.
} 
In the IFS statistics there is no position 'Net claims on Eurosystem' for the ECB or the non-Eurozone NCBs. Since the ECB itself does not publish its Target balances in its regular (weekly) financial statements, the only official data available are from the year-end accounts published in the ECB's Annual Report. For 31 December 2010 the official Target liability (which is actually denoted as 'Other liabilities within the Eurosystem (net)') of the ECB was 21 billion euros. The ECB's liabilities against the Eurosystem resulting from the transfer of foreign reserves amounted to 40 billion euros and the ECB's capital was 5 billion euros. Both positions should be the sum of the NCBs' corresponding claims. Thus, while the official net liabilities of the ECB against the Eurosystem (excluding the 'Claims related to the allocation of euro banknotes within the Eurosystem') amounted to 66.7 billion euros, the residual from the IFS proxy was only 41.8 billion euros. The gap between both figures is the error that we make when using the IMF proxy. A certain part of this gap may be explained by Target claims of non-Eurozone NCBs on the Eurosystem. These NCBs can also elect to connect to the Target payment system. Given that they are not part of the currency area, these NCBs have to maintain a positive balance vis-à-vis the ECB. ${ }^{45}$

Figure 15 shows the residual from the NCBs' IMF proxies (line) and the official IntraEurosystem claims (bars). The difference between these values as given by the dashed bars is rather constant over time and amounts to 35 billion euros on average. Since it is always positive, a large part of the measurement error is probably explained by the non-Eurozone NCBs' claims on the Eurosystem. The sharp increase of the Intra-Eurosystem claims at the end of 2008 was mainly due to back-to-back swap transactions conducted with NCBs in connection with US dollar liquidity-providing operations. These claims were continuously reduced in the course of 2009. In 2010 the net claim of the ECB vis-à-vis the NCBs related to Target transactions turned into a net liability for the first time since 1999. This liability was due mainly to purchases of securities under the covered bond purchase program and the Securities Markets Programme in 2010, which were settled via Target accounts. For the latest increase no official statements have so far been given by the ECB, but it can be presumed that the renewed intensification of the crisis has led the ECB to react in a way similar to $2008 / 2009$.

Figure 15: ECB - Intra-Eurosystem claims

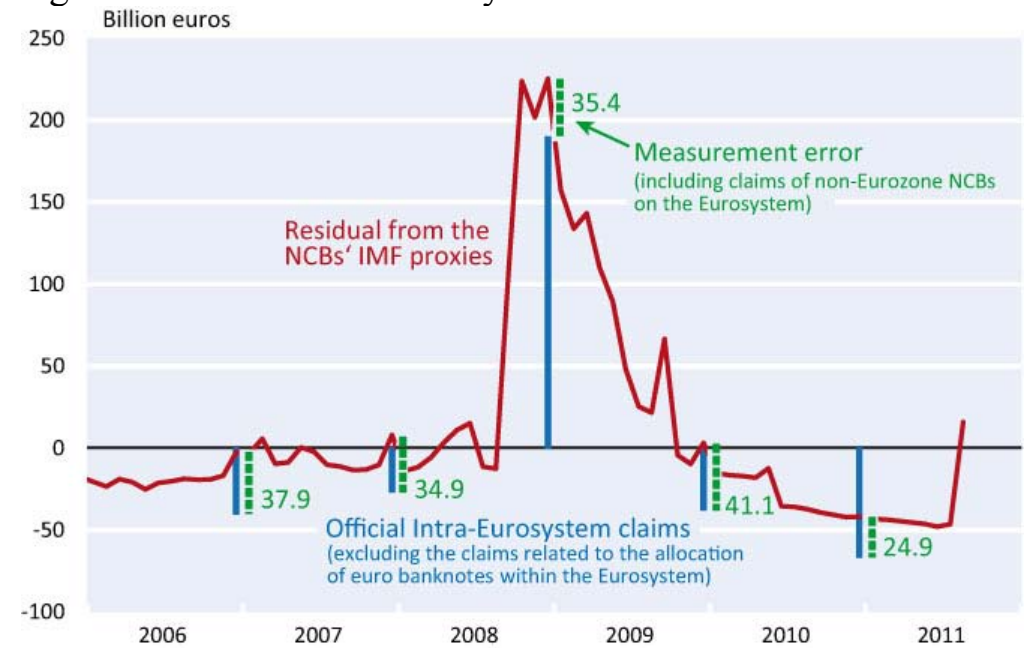

Sources: European Central Bank, Annual Report, various issues.

\footnotetext{
${ }^{45}$ European Central Bank (2011b, footnote 2).
} 
Apart from the balance sheet statistics of the central banks, the Target balances can also be found in the balance-of-payments statistics, where they are shown as a flow in the financial account under the 'Other Financial Transactions with Non-residents' position of the respective NCBs and as a stock in the international investment position of the respective NCBs as 'Assets/Liabilities within the Eurosystem'.

The claims listed in the external position of the Bundesbank within the Eurosystem (after deducting the Bundesbank's participating interest in the ECB and the claims arising from the transfer of foreign reserves to the ECB) rose from 5.4 billion euros at the end of 2006 to 325.6 billion euros at the end of 2010 (Bundesbank database, series EU8148). This refers again to the Target balance, as can be calculated from the Bundesbank's balance sheet. The cumulative capital exports of the Bundesbank in the financial accounts (subcategory Bank deposits, Bundesbank database, series EU4678) amounted to 319.3 billion euros from 2007 to 2010 and were thus practically as high as the difference in the Bundesbank's Target claims between the end of 2010 and the end of 2006, namely 320.2 billion euros. 